\title{
CMRO
}

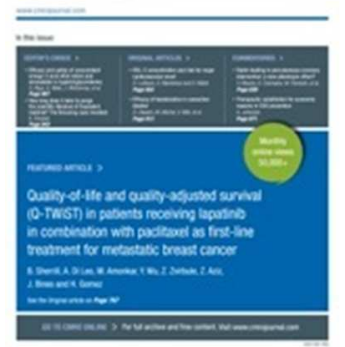

\section{Cost-effectiveness analysis of iStent trabecular micro- bypass stent for patients with open-angle glaucoma in Colombia}

\begin{tabular}{|r|l|}
\hline Journal: & Current Medical Research \& Opinion \\
\hline Manuscript ID & Draft \\
\hline Danuscript Type: & Original Article \\
\hline Complete List of Authors: & $\begin{array}{l}\text { Ordóñez, Jaime; True Consulting, HEOR; True Consulting, HEOR } \\
\text { Ordóñez, Angélica; True Consulting, HEOR } \\
\text { Osorio, Urpy; Organizacion Sanitas Internacional, Health Audit }\end{array}$ \\
\hline Keywords: & $\begin{array}{l}\text { cost-benefit analysis, open-angle glaucoma, ocular hypertension, stents, } \\
\text { minimally invasive surgical procedures, medication adherence }\end{array}$ \\
\hline \multicolumn{2}{|c}{} \\
\hline
\end{tabular}

SCHOLARONE ${ }^{\text {IM }}$

Manuscripts 


\title{
Cost-effectiveness analysis of iStent trabecular micro-bypass stent for patients with open-angle glaucoma in Colombia
}

\author{
Jaime E. Ordóñez ${ }^{a^{*}}$, Angélica Ordóñez ${ }^{\mathrm{a}} \&$ Urpy M. Osorio $^{\mathrm{b}}$ \\ ${ }^{a}$ True Consulting, Envigado, Colombia; ${ }^{b}$ Sanitas, Bogotá DC, Colombia
}

\author{
Corresponding author \\ Jaime E. Ordóñez, True Consulting; Carrera 27 A 36 Sur - 150 Int. 107, Envigado, Antioquia, \\ Colombia. \\ jaime.ordonez@trueconsulting.co \\ https://www.linkedin.com/in/jaime-eduardo-ord\%C3\%B3\%C3\%B1ez-molina-86a74512/
}

\section{Transparency section \\ Declaration of funding}

This research was funded by Glaukos (San Clemente, CA, USA). Researchers declare full independence of the contract and we are solely responsible for methods, results and concepts raised in this paper.

Declaration of financial/other relationship 
Dr. Jaime E. Ordóñez receives research support from Abbvie, AstraZeneca, Biogen Idec, Bristol Myers-Squibb, CES University, Colciencias, Colombian Society of Rheumatology, Corum, Glaukos, Metrosalud, Ministry of Health and Social Protection of Colombia, Ministry of Social Welfare of Medellin, Ministry of Health of Medellin, Novo Nordisk, Stendhal, Pfizer, University of Antioquia. Dr. Ordóñez is a consultant and/or on the advisory board of AstraZeneca, Bristol Myers-Squibb, Institute for the Surveillance of Medicines and Foods of Colombia (INVIMA), International Society for Pharmacoeconomics and Outcomes Research ISPOR-Colombia, Merck \& Co, Ministry of Education of Colombia, Ministry of Health and Social Protection of Colombia, Novo Nordisk, Stendhal and Pfizer (Colombia and USA). Dr. Ordóñez is also speaker for Abbvie, Bayer, CES University, International Society for Pharmacoeconomics and Outcomes Research ISPOR-Colombia, Novartis, Novo Nordisk (Colombia and Panama), Stendhal and Pfizer (Colombia, Ecuador, and Dominican Republic). All other coauthors have no commercial relationship to declare.

\section{Author contributions}

JEO was involved in formulation of the research question; protocol preparation; search, selection and evaluation of studies quality; quality control in data extraction; synthesis of the evidence; and manuscript writing.

AO was involved in model design; software programming; and manuscript writing.

UMO was involved in quality control in data extraction; synthesis of clinical evidence and costs; and manuscript writing.

\section{Acknowledgements}

No assistance in the preparation of this article is to be declared. 


\title{
Cost-effectiveness analysis of iStent trabecular micro-bypass stent for patients with open-angle glaucoma in Colombia
}

\author{
Abstract \\ Objective: To estimate cost-effectiveness of trabecular micro bypass stent versus laser trabeculoplasty or \\ medications only, for patients with open-angle glaucoma in setting of Colombian System Health. \\ Methods: This is a cost-effectiveness analysis that based its assumptions in external data sources, used to \\ extrapolate the quality of life related to health, survival and costs. A Markov model, with stages from 0 \\ (ocular hypertension without glaucoma) to 5 and bilateral blindness, was developed inclusive of \\ Colombian older than 40 years in 2018 , from a societal perspective, comparing trabecular micro-bypass \\ stents versus, laser trabeculoplasty, timolol+dorzolamide+brimonidine, timolol+dorzolamide+latanoprost, \\ or timolol+dorzolamide+brimatoprost, in terms of clinical and economic outcomes over a lifetime \\ horizon. Both costs and health outcomes had an annual rate discount of 5\%. Health outcomes were \\ evaluated in terms of QALYs related with loss of visual acuity. Trabecular micro-bypass costs include the \\ joint use of timolol, the costs of laser trabeculoplasty include the combined use of timolol+dorzolamide. \\ Results: Trabecular micro-bypass stents were estimated to have 127,971 more discounted QALYs, versus \\ laser trabeculoplasty; 405,982, versus timolol+dorzolamide+brimonidine; and 378,287, versus \\ timolol+dorzolamide+latanoprost or timolol+dorzolamide+brimatoprost. Cumulative costs with \\ trabecular micro-bypass stents at 40 years was $\$ 13,252,318$ lower than laser trabeculoplasty; $\$ 6,403,534$, \\ lower than timolol+dorzolamide+brimonidine; $\$ 22,311,064$, lower than \\ timolol+dorzolamide+latanoprost; and $\$ 29,156,113$ lower than timolol+dorzolamide+brimatoprost.
}


Conclusions: Trabecular micro-bypass stent is a highly cost-saving strategy due to more QALYs related to a lower rate of the population with loss of visual acuity in the long term, and because the costs associated with additional medications and complications are lower with trabecular micro-bypass stents.

Keywords: cost-benefit analysis; open-angle glaucoma; ocular hypertension; stents; minimally invasive surgical procedures; medication adherence

Short title: Cost-effectiveness of trabecular micro-bypass stent in Colombia

\section{Introduction}

Open-angle glaucoma $(\mathrm{OAG})$ represents approximately $70 \%$ of glaucoma cases in the world. Its prevalence has been increasing, probably due to the increase and improvement of diagnostic technology methods [1]. World prevalence of glaucoma in people between 40 and 80 years was estimated at 64,3 million in 2013 , and it is projected that by 2020 it will increase to 76 million people [2]. There are many estimates of glaucoma prevalence that differ among them, mainly because of the differences in age and racial structures of the populations. The prevalence adjusted for age shows that, in African-American people, this is four to five times higher than in non-Hispanic whites. A population-based study showed that the annual incidence of OAG in a population of white majority in the USA, is 14.5 per 100,000 people, which increases with age, going from 1.6 per 100,000 in fourth decade of life to 94.3 per 100,000 people in life eighth decade [3].

In Latin America there are not many epidemiological studies that quantify prevalence of glaucoma, however, there are data from different studies in some countries of the region, either 
hospital-based or derived from screening studies. In Peru, a glaucoma prevalence of $1.9 \%$ was estimated in patients older than 30 years, diagnosed by indentation tonometry and direct funduscopy [4]. In the RACSS study in Brazil, it was found that $11.4 \%$ of blindness is attributed to glaucoma [5]. However, this prevalence was higher in patients older than 50 years, in which $20 \%$ of cases of blindness were attributed to glaucoma [6]. In an ophthalmologic hospital in Ecuador, was observed a blindness prevalence of $17 \%$ related to glaucoma, but this could be due to the way of selecting the sample, because that study is not based in general population [7]. Visual health situation in Colombia found out 238,846 people with glaucoma generate 450,084 health care activities, representing $0.08 \%$ of total health care in the country (8).

Proven treatment to reduce glaucoma risk progression is to decrease intraocular pressure (IOP) through topical medications. Among most commonly used are prostaglandin analogs, $\beta$ adrenergic agonists, carbonic anhydrase inhibitors, $\alpha$-adrenergic agonists, and miotic agonists, such as pilocarpine [9]. Although monotherapy is most usual strategy at disease beginning, as the severity of glaucoma increases, different combinations of these medications are used. Main problem faced by patients, besides to polypharmacy secondary effects, is noncompliance medication and their insufficient ability to apply them, which affects clinical effectiveness. Surgical procedures such as selective laser trabeculoplasty have shown good clinical outcomes. Recent use of trabecular micro-bypass stent by means of minimally invasive glaucoma surgery (MIGS) has shown great outcomes. 
As glaucoma is a chronic disease whose damage to optic disc is not reversible, it is necessary to consider different treatment strategies in a scenario that evaluates both costs and clinical outcomes during patients lifetime horizon, with the purpose of generating information that allow to decision makers to identify treatment strategy that offers best clinical outcomes, adjusted to economic reality of Colombian health system.

\author{
Methods \\ Target population \\ Patients with mild to moderate glaucoma, includes visual field defects or characteristic optic \\ nerve abnormalities consistent with mild to moderate glaucoma and cup-disk ratio no worse than \\ 0.8 , and with a medicated IOP of $24 \mathrm{mmHg}$ of less, receiving from one to three medications. \\ Patients with angle-closure glaucoma, secondary glaucoma (except pseudoexfoliative and \\ pigmentary), severely uncontrolled IOP, severe glaucomatous field defects, previous glaucoma \\ surgery (except iridectomy), with previous refractive procedures, and monocular patients or \\ patients with visual acuity (VA) corrected lesser than 20/200 in the other eye, were excluded.
}

\title{
Study perspective
}

The perspective of the analysis is from the General System of Social Security in Health of Colombia, this implies identifying the direct costs of the resources associated with the use of these technologies, included or not in the Plan of Benefits of Health of Colombia [10], and the health outcomes perceived by patients. 


\section{Comparators}

Trabecular micro-bypass stent through the MIGS targets three main flow channels: the suprachoroidal space through uveoscleral pathway, Schlemm channel through trabecular flow, and subconjuntival space, thus creating an alternative flow path for aqueous humor, with an approach internal and minimal trauma, being a very safe procedure with a patient quick recovery. Goal of this surgery is to fill gap between medical treatment and more invasive surgeries such as trabeculectomy [11]. Many micro-invasive surgeries are performed simultaneously with cataract surgery. iStent ${ }^{\circledR}$, an intraocular stent manufactured in titanium and covered with heparin in an Lshaped structure, is one of most widely used and studied micro-invasive surgery devices.

Prostaglandin analogs are commonly used as first line treatment due mainly to lack of systemic side effects and convenience of daily dose, except for unoprostone, which usually promotes adherence. They are contraindicated in patients with reactive airway or with renal failure. Adverse effects of this group of medications include ocular hyperpigmentation, conjunctival injection, allergic conjunctivitis, contact dermatitis, keratitis, possible reactivation of the herpes virus, uveitis, increased pigmentation of the iris, cystoid macular edema and periorbitopathy [12].

$\beta$-adrenergic agonists are currently most used group of topical medications. There are two classes of $\beta$-blockers, nonselective ones that bind to $\beta 1$ and $\beta 2$ receptors and include timolol maleate, hemihydrate, levobunol, carteolol and metipranolol. Mechanism by which blockade of $\beta$ - 
receptors leads to a decrease in production of aqueous humor and consequently to a reduction in IOP, is not known. Apparently, aqueous humor production is activated by a cyclic AMP-PKA pathway mediated by $\beta$ receptors [13]. Possible side effects include keratitis, allergic conjunctivitis, bronchospasm, depression hypotension, bradycardia, etc. [12].

$\alpha$-adrenergic agonists activate $\alpha 1$ receptors that simulate contraction of iris dilator muscle Müller muscles, leading go mydriasis and retraction of eyelid. Also, $\alpha 1$ stimulation leads to vasoconstriction, which results in restricted blood flow to ciliary muscle and a reduction in aqueous humor production [14]. Among its possible adverse effects are allergic and follicular conjunctivitis, hypotension, fatigue, headache and somnolence [12].

Carbonic anhydrase inhibitors were initially introduced as effective oral diuretic agents, subsequently used for glaucoma treatment, and have been found to lower IPO by reducing aqueous humor production in ciliary body [15]. For a long time, systemic treatment with carbonic anhydrase inhibitors was one of most important components for glaucoma treatment, however, it lost importance with introduction of the topical form in 1995. Systemic drug is currently reserved for short term treatments in patients with maximum doses of medical therapy, or when other treatments have not achieved the patient' goal to decrease IOP. Potential adverse effects of this therapy include corneal edema and keratitis [16].

\footnotetext{
Pilocarpine ophthalmic is a natural alkaloid obtained from Pilocarpus Jaborandi leaves, and its effect on dynamics of aqueous humor is complicated and not completely understood. It is
} 
believed that main mechanism to reduce IOP is flow increase, in the same way, parasympatheticmimetic stimulation contracts ciliary muscle and produces an internal movement of scleral spur to which it is attached. This produces a structural change in trabeculum, allowing an increase in aqueous flow. IOP reduction begins 60 minutes after its application and peaks at 75 minutes, lasting four to eight hours, depending on dose [17]. However, these parasympathetic-mimetic agents could produce adverse effects such as increased myopia, cataracts, periocular dermatitis, allergic conjunctivitis, decreased VA, conjunctival contraction, conjunctival scars, keratitis, among others [12].

Selective laser trabeculoplasty works in the same way as argon laser trabeculoplasty, flanking the trabecular meshwork by means of an Nd YAG laser applying shocks of shorter energies, causing less damage. This surgery is a good option for elderly patients with little adherence or low tolerance to topical medication, and who are not candidates for trabeculectomy. It is a relatively non-invasive procedure that takes approximately 10 to 20 minutes. A systematic review of 19 studies showed that there is no significant difference between laser-selective trabeculoplasty and argon laser trabeculoplasty when comparing decrease in IOP [18].

\section{Time horizon}

Although there are trials with trabecular micro-bypass stent with up to four years of follow-up [19], most of clinical trials about drugs for ocular hypertension treatment are followed for three months and some for up to one year. Although the natural history of glaucoma exceeds this time, it was not possible to obtain randomized controlled trials (RCTs) that considered a longer time 
horizon that would have impact on clinical outcomes. We consulted with clinical experts about time horizon that could reflect in a better way of treatment strategies effectiveness evaluated in the model, who agreed to structure it with population lifetime horizon, with decision points every year, to evaluate mortality rate. This time horizon is necessary because this is a chronic disease that can start when patients are still young adults and they are going to suffer it throughout all their lives.

\section{Discount rate}

A discount rate of $5 \%$ was used for both costs and benefits. This is considered the discount rate that best fits Colombian context and is also discount rate recommended by Institute of Technological Evaluation in Health in Colombia [20].

\section{Choice of health outcomes}

Three outcomes were chosen; first, hip fractures avoided due to VA loss; second, Life-Years Gained (LYGs) for premature deaths avoided due to hip fractures; third, lost Quality Adjusted Life-Years (QALYs) by VA decrease and loss. QALYs allow to capture both Quality of Life (QoL) related with health and time, that is, a qualitative variable and a quantitative variable simultaneously, this is so important because glaucoma is a chronic disease and its treatment' goal is to decrease losing vision risk during patient's life. About clinical outcomes, an adjustment by loss of QALYs due to chronic noncommunicable diseases was made, based on a study that found out QALYs loss in patients between 20 and 80 years of age with cataracts [21]. 


\section{Measurement of effectiveness}

Several systematic reviews were carried out to identify clinical efficacy, using same search strategy for each comparator, which included the MeSH term for each drug or laser selective trabeculoplasty, and term primary OAG (POAG). We searched for metanalysis of RCTs; in case they were not obtained, we searched for RCTs that met GRADE bias control criteria [22].

\section{Estimating resources and costs}

A search was made of individual costs of all interventions, procedures and medicines required from database of a Health Maintenance Organization (HMO) of Colombia, with a national presence and with data for year 2017. Drug Price Information System of Colombia (SISMED, Spanish acronym) was used to take drug costs for ocular hypertension treatment, and weighted mean was calculated for every strategy evaluated. Then, costs were estimated for each one drug strategy for ocular hypertension treatment, as well as costs of ophthalmological surgeries and hip arthroplasty in individual with hip fracture due to VA loss (Table 1). For costs calculation in patients undergoing ophthalmic or orthopedic surgery, a top-down methodology was used, based on hospital invoices of HMO.

\section{Currency, price data, and conversion}

Costs are originally calculated in Colombian pesos (COP) and later were converted into American dollars (USD), based on a mean exchange rate of COP 3,000 for USD 1. 


\section{Choice of model}

This is a cost-effectiveness decision model with a Markov structure to estimate costs and longterm health outcomes (Figure 1). Model structure is based on natural history of ocular hypertension and its relationship with POAG. Model stages of are based on paper of Mills et al about glaucoma categorization from disease pre-diagnosis to its final state [23], which is currently most used to describe glaucoma natural history. Model includes entire population over 40 years old with ocular hypertension, with or without treatment. Annual Markov cycles are applied in a patient cohort progressing through Markov model, according to estimated transition probabilities.

Given that duration of most RCTs evaluating drug's efficacy for ocular hypertension treatment are three months and that model' cycles last one year, it is assumed that patients will be evaluated four times by ophthalmologist during each cycle, at which time, probability of continuing in same stage, changing status or dying, will apply. Model does not assume glaucoma deaths, so death probability of model is mortality rate of general population. Model has 40 cycles from when individuals enter until they die with a lifetime horizon of 80 years. Cohort of model is dynamic during the 40 cycles, this means that individuals who are under 40 years old at time of model initiating, will enter when they are 40 years old.

Assumptions. 
This decision model considers following assumptions with respect to comparators:

- In all patients with MIGS for implantation of a trabecular micro-bypass stent, it is assumed that they continue to receive timolol during their lifetime horizon.

- In all patients with laser trabeculoplasty surgery, it is assumed that they continue to receive timolol + dorzolamide during lifetime horizon .

- All patients with medicines only, receive two or three drugs simultaneously; it is assumed that no one receive monotherapy because of its high failure treatment rate.

- Combinations of two or three drugs estimated in this decision model, which are assumed to be most used by ophthalmologists, are:

$$
\begin{array}{ll}
\circ \text { Latanoprost + Timolol + Dorzolamide } \\
\circ \text { Bimatroprost + Timolol + dorzolamide } \\
\circ \text { Travoprost + Timolol + Dorzolamide } \\
\circ \text { Brimonidine + Timolol + Dorzolamide } \\
\circ \text { Timolol + Travaprost } \\
\text { ○ Timolol + Travaprost (Bak Free) } \\
\circ \text { Timolol + Brinzolamide } \\
\circ \text { Timolol + Brimonidine } \\
\circ \text { Brimonidine + Brinzolamide }
\end{array}
$$

Analytic methods. 
Survival analysis was used to determine risk of every clinical pathway and to derive Markov cycles probabilities. Drug adverse events ocular hypertension treatment are not modeled because most of it disappear quickly when medication is interrupted, so cost structure is not affected.

Model has two main features: the QALYs adjustment over time, and hip fracture as a complication related to VA reduction. QALY adjustment over time is justified by impact of chronic noncommunicable diseases (NCDs) over burden of disease in world. For this purpose, a study that estimated QALYs loss in adults from South Korea according to 13 NCDs in 2010, including cataracts, was used. This study found out that when weighting utility for some NCDs according to sex and age, in some cases utility did not decrease as the age increased, for example, myocardial infarction in women between 20 and 29 years old. On the other hand, NCDs most affect QALYs loss due to morbidity are cataracts, hyperlipidemia and depression [21]. Importance of this concept is that, most times, lost QALYs increase as the population ages, therefore QALYs change over time.

Regarding hip fracture as an outcome of this model, it is justified because falls, particularly associated with injuries, are a problem of public health for elderly in the world. About $30 \%$ of people over 65 have a fall at least once a year, $10 \%$ - $20 \%$ of these falls cause injuries and $5 \%$ $6 \%$ result in fractures [24]. In 2010, there were 21,649 deaths due to falls among people $>65$ years in US [25]. Falls are not only associated with physical consequences, they are also associated with a decrease in quality of life and other events, such as depression, fear of another fall, restricted activity, hospitalization and subsequent admission to a nursing home. Greater risk 
of falls in elderly is aggravated by visual impairment, and this has been a consistent finding in several studies [26-28].

In fact, a metanalysis found that relative risk of a fall in people whose visual impairment was caused by visual field loss or glaucoma, was greater compared to population with general disability [29]. A recent study showed that best corrected VA in the eye and in worst eye of patients with POAG was significantly associated with falls [26]. Some studies have reported that VA in worst eye is a risk factor for falls in elderly [30,31].

Finally, considering that glaucoma is a NCD that still has no cure, whose treatment is aimed at reducing disease worsening rate and that involves daily application of several medicines, has a problem of nonadherence to treatment, which affects its clinical effectiveness and model outcomes. Adherence or compliance to a medication regimen is generally defined as extent to which patients take medications as prescribed by their health care providers [32]. Noncompliance can be due to failures in form of taking a medication, doing it at wrong time, taking an incorrect medication or, rarely, taking them excessively. However, in ocular diseases, noncompliance could even result from an inadequate technique of medication administration.

\section{Results \\ Study parameters.}


Model allows to adjust frequency distribution of glaucoma according to disease severity level and patients age group. In this cost-effectiveness analysis, it was decided to start with $100 \%$ of population in stage 0 (zero), that is, with ocular hypertension, with minimal or no defect, and that they do not meet criteria required for disease stage 1 according to Mills et al [23]. Disease prevalence assumes distribution indicated in Visual Health Situation Analysis of Colombia in 2016 (Table 2) [8]. Clinical outcome of model was patients rate who had a decrease $>20 \%$ in baseline IOP, measure reported by most RCTs. Table 3 shows mean, minimum and maximum values of clinical efficacy of each one strategy.

Drugs adherence for ocular hypertension treatment in this model was determined in $50 \%$, which was established based on four clinical studies that had different values: Okeke et al, $54 \%$ [54]; Gupta et al, $10 \%$ [55]; Campbell et al, $33.9 \%$ (bimatoprost $0.03 \%$ ) to $48.8 \%$ (bimatoprost 0.01 $\%)$ [56]; and Barnebey et al, $32 \%$ [57]. Transition annual probabilities between the five stages of glaucoma were taken from a study about resources use according to disease severity level (Table 4) [58]. In the same way, risk of developing unilateral blindness without treatment is $40.5 \%$, and bilateral, $16.5 \%$, according to a mathematical model that estimates glaucoma progression [59]. QALYs were taken from a cross-sectional study done in US that calculated utilities for five ophthalmological diseases, according to disease severity level (Table 5) [60].

\footnotetext{
QALYs for VA loss caused by glaucoma were adjusted during patients' lifetime horizon, based on calculation made by Ock [21]. Hip fracture incidence in older adults, adjusted by age group, was taken from Dirani et al, as follows: $60-69 \%$ years, $0.10 \% ; 70-79$ years, $0.40 \%$; and >
} 
80 years, $1.90 \%$ [29]. From the same study, risk ratio (RR) of having a hip fracture according to glaucoma clinical stage in comparison with healthy people, was taken (Table 6), which was only applied to patients $>60$ years of age, who have a higher risk of fall and fracture. Likewise, hip fracture lethality risk was taken from CHANCES project, that evaluated mortality excess from this cause in older adults in US and Europe [61], expressed as Hazard Ratio (HR) (Table 7), which was used for adjusting general mortality rate of Colombia, according to National Administrative Department of Statistics report (DANE, in Spanish) [62].

Finally, Gupta et al [55] found out that in patients with glaucoma who had more than six months of treatment, waste of ophthalmic drops due to failure by its application is $38 \%$. This value was applied to amount of medicines used by patients every year, thus adjusting healthcare costs for population with glaucoma.

\section{Incremental costs and outcomes.}

These are deterministic results of base case, comparing cost-effectiveness ratio of trabecular micro-bypass stent versus selective laser trabeculoplasty surgery and different medications combination for ocular hypertension treatment (Table 8). Trabecular micro-bypass stent is a dominant strategy versus all other treatment strategies of POAG. iSent ${ }^{\circledR}$ total costs discounted during population lifetime horizon are lower than those of other comparators. Likewise, discounted QALYs of trabecular micro-bypass stent in this population are greater than those of all other comparators, this means that versus laser selective trabeculoplasty and all medications 


\begin{abstract}
schemes for ocular hypertension treatment, total costs of iStent ${ }^{\circledR}$ are lower and its QALYs are higher.
\end{abstract}

\title{
Characterizing uncertainty.
}

It has been suggested a discount rate of $5 \%$ in Colombia (which was applied in the results of table 8), but really there is no empirical argument to ensure what is ideal value to make this calculation. For this reason, results of this evaluation are presented with different discount rates: $3.5 \%$ (Table 9) and $10 \%$ (Table 10). In the same way, we have estimated ICER through a oneway analysis with the minimum and maximum effectiveness (Table 11) and costs (Table 12) of every strategy.

To evaluate model robustness, a probabilistic sensitivity analysis was performed through a Monte Carlo simulation with 5,000 iterations. These results are reported through bivariate analyzes between trabecular micro-bypass stent versus every comparator by means of tornado diagrams (Figures 2-11), as well as through multivariate analysis using cost-effectiveness plane (Figure 12) and willingness-to-pay curve (Figure 13).

\section{Discussion}

Trabecular micro-bypass stent (+ timolol) is a dominant strategy versus trabeculoplasty laser surgery (+ timolol + dorzolamide) and the different medicines schemes for POAG treatment in Colombia. Discounted total costs with trabecular micro-bypass stent strategy after follow-up 
during population lifetime horizon were \$22,018,077 and discounted total QALYs were 2,226,612. These costs were lower than those of all comparators and QALYs were higher than those obtained by any of other strategies. Strategy most bring closer to micro-bypass stent in terms of costs was brimonidine + timolol + dorzolamide, whose discounted total costs were $\$$ 28,422,312; all other strategies had higher costs. Likewise, strategy that most approached to trabecular stent with respect to QALYs was laser surgery + timolol + dorzolamide, which obtained 2,098,641 QALYs.

This result remains constant in scenarios with different discount rates, both lower and higher than $5 \%$, which was the value used in base case scenario. With a discount rate of $0 \%$, total discounted costs of trabecular micro-bypass stent were $\$ 24,511,411$ and its total discounted QALYs were 3,438,382, this trabecular stent being the strategy with the lowest costs and highest QALYs. With a discount rate of $3.5 \%$, total discounted costs of trabecular micro-bypass stent were $\$ 22,522,209$ and its total discounted QALYs were 3,382,719. Again, trabecular microbypass stent was strategy with lowest cost and highest QALYs (Table 9). Based on above, it can be assumed that discount rate does not affect results of base case, that is, trabecular micro-bypass stent is a dominant strategy versus the other strategies, regardless of discount rate.

In one-way sensitive analysis (OWA), when assigning maximum effectiveness value to every comparator versus mean effectiveness of trabecular micro-bypass stent (69.1\%), results obtained in base case do not change, trabecular micro-bypass stent continues being dominant versus all other comparators. Comparator with a higher effectiveness is selective trabeculoplasty laser + 
timolol + dorzolamide, which has a maximum effectiveness of $29 \%$. Similarly, when assigning minimum value of effectiveness to trabecular micro-bypass stent $(58.7 \%)$ versus the mean effectiveness of all other strategies, there were no changes in results with respect to those observed in base case, in which trabecular micro-bypass stent is dominant versus all other comparators (Table 11).

Continuing with OWA, when assigning minimum cost to every comparator versus mean cost of trabecular micro-bypass stent ( $\$ 1,417$, the first year), this strategy is still dominant versus all comparators. The comparator with a lower cost than others, is the combination brimonidine + timolol + dorzolamide (\$ 311). Similarly, when assigning maximum cost to trabecular microbypass stent versus mean cost of all other strategies evaluated, there were no changes in the results versus the base case, in which trabecular micro-bypass stent is dominant versus the other comparators (Table 12). In bivariate analysis, which compares each one result of trabecular micro-bypass stent versus every strategy, costs and effectiveness of each strategy had the greatest weight on cost-effectiveness.

\footnotetext{
About multivariate sensitivity analyzes, in cost-effectiveness plane, trabecular micro-bypass stent was in center of plane and all other strategies were in northwest quadrant, that is, all strategies were dominated by the trabecular micro-bypass stent, since their costs were higher and their QALYs lower versus trabecular micro-bypass stent (Figure 12). In willingness-to-pay curves, trabecular micro-bypass stent had a $100 \%$ probability of being the chosen strategy, with any availability value to pay (Figure 13).
} 
Results of sensitivity analysis shows robustness of results of base case, since in all scenarios dominance of trabecular micro-bypass stent $(+$ timolol) is maintained versus laser selective trabeculoplasty (+ timolol + dorzolamide) and all combinations of medicines for ocular hypertension treatment, included in this economic evaluation. That is, trabecular micro-bypass stent is a cost-saving strategy for treatment of patients with POAG in Colombia. Although its cost is higher in first year, total discounted costs are lower at end of follow-up, since this higher cost is due to device that is implanted only once versus other strategies that must use simultaneous combination of several medications throughout patient's lifetime horizon, which have less clinical efficacy and that generates more costs due to the complications related to VA loss, such as hip fracture.

Trabecular micro-bypass stent is a technology that has been evaluated for a decade, and although there is profuse literature about its safety and clinical efficacy, there are still few economic evaluations on it. Recently, Berdahl et al published a cost study in which they compared this trabecular micro-bypass stent with the selective laser trabeculoplasty or drug treatment, in which they found that, despite its higher costs in year zero, thereafter, they were lower yearly in patients with trabecular micro-bypass stent. For this reason, authors concluded that trabecular micro-bypass stent can reduce use of health resources in relation to POAG, which generates direct savings, especially regard to medications in time horizons of more than one year [63], results that are like those of this economic evaluation. 
During question refinement, there were sociodemographic considerations related to complications about disease natural history. For this purpose, Dirani study [29] was considered about economic impact of glaucoma in Australia, in which authors considered risk of falling and hip fracture due to decreased VA. Although a variety of economic studies have been published about diagnostic and treatment strategies for POAG management (Berdahl et al [63], Pizzi et al [64], Javanbakht et al [65], Boodhna et al [66], Kaplan et al [67], Patel et al [68], among others), none has considered hip fracture outcome due to VA loss as an outcome directly related to POAG. This outcome was considered because population most affected by POAG are $>40$ years, and population with highest risk of hip fracture are adults $>60$ years.

Main limitation of this economic evaluation is follow-up of population during their lifetime horizon, which for this study is 80 years, that means that this follow-up lasted a maximum of 40 years. For such a long-time uncertainty is greater; because although it is unlikely that clinical efficacies of these technologies will change, the other variables can do it. During this period, prices of all strategies can decrease (it is foolhardy to establish magnitude of such decrease); lifetime horizon is likely to increase, which would increase risk of hip fracture; diagnosis and treatment of hip fracture could change in elderly; new technologies will generate previously unknown information. These uncertainties would affect all comparators equally, thus reducing risk of bias that they generate about results of this study.

\section{References}


1. Beidoe G, Mousa SA. Current primary open-angle glaucoma treatments and future directions. Clin Ophthalmol. 2012; 6: 1699-707.

2. Tham YC, Li X, Wong TY, Quigley HA, Aung T, Cheng CY. Global prevalence of glaucoma and projections of glaucoma burden through 2040: a systematic review and meta-analysis.

3. Cedrone C, Mancino R, Cerulli A, Cesareo M, Nucci C. Epidemiology of primary glaucoma: prevalence, incidence, and blinding effects. Prog Brain Res. 2008; 173: 3-14.

4. Viaña JM, Pongo L, Castro H, Corbera JC. Incidencia del glaucoma en la región Grau. Rev peruana Oftalmol. 1995; 19: 23-5.

5. Arieta CE, de Oliveira DF, Lupinacci AP, Novaes P, Paccola M, Jose NK, Limburg H. Cataract remains an important cause of blindness in Campinas, Brazil. Ophthalmic Epidemiology. 2009; 16(1): 58-63.

6. Salomao SR, Cinoto RW, Berezovsky A, Araujo-Filho A, Mitsuhiro MR, Mendieta L, et al. Prevalence and causes of vision impairment and blindness in older adults in Brazil: the Sao Paulo Eye Study. Ophthalmic Epidemiology. 2008; 15(3): 167-75.

7. Cass H, Landers J, Benitez P. Causes of blindness among hospital outpatients in Ecuador. Clin Exp Ophthalmol. 2006; 34(2): 146-51.

8. Ministerio de Salud y Protección Social, Organización Panamericana de la Salud. Análisis de situación de situación de salud visual en Colombia. Bogotá DC: Ministerio de Salud y Protección Social; 2016.

9. Jonas JB, Aung T, Bourne RR, Bron AM, Ritch R, Panda-Jonas S. Glaucoma. Lancet. 2017; 390(10108): 2183-93. 
10. Ministerio de Salud y Protección Social. Resolución 5269 de 2017, by which the Health Benefits Plan is updated with charge to the Capitation Payment Unit (UPC, by its acronym in Spanish) (22 Dec 2017).

11. Saheb H, Ahmed IIK. Micro-invasive glaucoma surgery: current perspectives and future directions. Current Opin Ophthalmol. 2012; 23(2): 96-104.

12. Prum Jr BE, Lim MC, Mansberger SL, Stein JD, Moroi SE, Gedde SJ, et al. Primary Open-Angle Glaucoma Suspect Preferred Practice Pattern ${ }^{\circledR}$ Guidelines. Ophthalmology. 2016; 123(1): P112-P51.

13. Henderer JD, Rapuano CJ. Ocular Pharmacology. In: Brunton LL, Chabner BA, Knollmann BC, editors. Goodman \&amp; Gilman's: The Pharmacological Basis of Therapeutics, 12e. New York, NY: McGraw-Hill Education; 2011.

14. Docherty JR. Subtypes of functional aplha1-adrenoceptor. Cell Mol Life Sci. 2010; 67(3): 405-17.

15. Becker B. The effects of the carbonic anhydrase inhibitor, acetazoleamide, on the composition of the aqueous humor. Am J Ophthalmol. 1955; $40(5$ Pt 2): 129-36.

16. Epstein DL, Grant WM. Carbonic anhydrase inhibitor side effects. Serum chemical analysis. Arch Ophthalmol. 1977; 95(8): 1378-82.

17. Zimmerman TJ. Pilocarpine. Ophthalmology. 1981; 88(1): 85-8.

18. Rolim de Moura C, Paranhos A Jr, Wormald R. Laser trabeculoplasty for open angle glaucoma. Cochrane Database Syst Rev. 2007; (4): CD003919.

19. Arriola-Villalobos P, Martinez-de-la-Casa JM, Diaz-Valle D, Morales-Fernandez L, Fernandez-Perez C, Garcia-Feijoo J. Glaukos iStent inject ${ }^{\circledR}$ trabecular micro-bypass implantation associated with cataract surgery in patients with coexisting cataract and 
open-angle glaucoma or ocular hypertension: a long-term study. J Ophthalmol. 2016; 2016: 1056573.

20. Instituto de Evaluación Tecnológica en Salud. Manual para la elaboración de evaluaciones económicas en salud. Bogotá D.C.: IETS, 2014.

21. Ock M, Han JW, Lee JY, Kim SH, Jo MW. Estimating quality-adjusted life-year loss due to noncommunicable diseases in Korean adults through to the year 2040. Value Health. 2015; 18(1): 61-6.

22. Atkins D, Eccles M, Flottorp S, Guyatt GH, Henry D; GRADE Working Group, et al. Systems for grading the quality of evidence and the strength of recommendations I: critical appraisal of existing approaches The GRADE Working Group. BMC Health Serv Res. 2004; 4(1): 38 .

23. Mills RP, Budenz DL, Lee PP, Noecker RJ, Walt JG, Siegartel LR, et al. Categorizing the stage of glaucoma from pre-diagnosis to end-stage disease. Am J Ophthalmol. 2006; 141(1): 24-30.

24. Tinetti ME, Speechley M, Ginter SF. Risk factors for falls among elderly persons living in the community. N Engl J Med. 1988; 319(26): 1701-7.

25. Stevens JA, Rudd RA. Circumstances and contributing causes of fall deaths among persons aged 65 and older: United States, 2010. J Am Geriatr Soc. 2014; 62(3): 470-5.

26. Yuki K, Asaoka R, Tsubota K. Investigating the influence of visual function and systemic risk factors on falls and injurious falls in glaucoma using the structural equation modelling. PLoS One. 2015; 10(6): e0129316. 
27. Skalska A, Wizner B, Piotrowicz K, Klich-Rączka A, Klimek E, Mossakowska M, et al. The prevalence of falls and their relation to visual and hearing impairments among a nation-wide cohort of older Poles. Exp Gerontol. 2013; 48(2): 140-6.

28. Hong T, Mitchell P, Burlutsky G, Samarawickrama C, Wang JJ. Visual impairment and the incidence of falls and fractures among older people: longitudinal findings from the Blue Mountains Eye Study. Invest Ophthalmol Vis Sci. 2014; 55(11): 7589-93.

29. Dirani M, Crowston JG, Taylor PS, Moore PT, Rogers S, Pezzullo Ml, et al. Economic impact of primary open-angle glaucoma in Australia. Clin Exp Ophthalmol. 2011; 39(7): 623-32.

30. Lin CH, Liao KC, Pu SJ, Chen YC, Liu MS. Associated factors for falls among the community-dwelling older people assessed y annual geriatric health examinations. PLos One. $2011 ; 6(4)$ : e18976.

31. Lord SR, Dayhew J. Visual risk factors for falls in older people. J Am Geriatr Soc. 2001; 49(5): 508-15.

32. Osterberg L, Blaschke T. Adherence to medication. N Engl J Med. 2005; 353(5): 487-97.

33. van der Valk R, Webers CA, Lumley T, Hendrikse F, Prins MH, Schouten JS. A network meta-analysis combined direct and indirect comparisons between glaucoma drugs to rank effectiveness in lowering intraocular pressure. J Clin Epidemiol. 2009; 62(12): 1279-83.

34. Lin L, Zhao YJ, Chew PT, Sng CC, Wong HT, Yip LW, et al. Comparative efficacy and tolerability of topical prostaglandin analogues for primary open-angle glaucoma and ocular hypertension. Ann Pharmacother. 2014; 48(12): 1585-93. 
35. Brandt JD, Cantor LB, Katz LJ, Batoosingh Al, Chou C, Bossowska I; Ganfort Investigators Group II. Bimatoprost/timolol fixed combination: a 3-month doublemasked, randomized parallel comparison to its individual components in patients with glaucoma or ocular hypertension. J Glaucoma. 2008; 17(3): 211-6.

36. Craven ER, Walters TR, Williams R, Chou C, Cheetham JK, Schiffman R; Combigan Study Group. Brimonidine and timolol fixed-combination therapy versus monotherapy: a 3-month randomized trial in patients with glaucoma or ocular hypertension. J Ocul Pharmacol Ther. 2005; 21(4): 337-48.

37. Silver LH. Clinical efficacy and safety of brinzolamide (Azopt), a new topical carbonic anhydrase inhibitor for primary open-angle glaucoma and ocular hypertension. Brinzolamide Primary Therapy Study Group. Am J Ophthalmol. 1998; 126(3): 400-8.

38. Bucci MG. Intraocular pressure-lowering effects of latanoprost monotherapy versus latanoprost or pilocarpine in combination with timolol: a randomized, observer-masked multicenter study in patients with open-angle glaucoma. Italian Latanoprost Study Group. J Glaucoma. 1999; 8(1): 24-30.

39. Centofanti M, Oddone F, Vetrugno M, Manni G, Fogagnolo P, Tanga L, et al. Efficacy of the fixed combinations of bimatroprost or latanoprost plus timolol in patients uncontrolled with prostaglandin monotherapy: a multicenter, randomized, investigatormasked, clinical study. Eur J Ophthalmol. 2009; 19(1): 66-71.

40. Higginbotham EJ, Olander KW, Kim EE, Grunden JW, Kwok KK; United States FixedCombination Study, et al. Fixed combination of latanoprost and timolol vs individual components for primary open-angle glaucoma or ocular hypertension: a randomized, double-masked study. Arch Ophthalmol. 2010; 128(2): 165-72. 
41. Hoy SM, Keam SJ, Keating GM. Tavoprosto/timolol. Drugs Aging. 2006; 23(7): 587-97.

42. Schuman JS, Katz GJ, Lewis RA, Henry JC, Mallick S, Wells DT, et al. Efficacy and safety of a fixed combination of travoprost $0.004 \% /$ timolol $0.5 \%$ ophthalmic solution once daily for open-angle glaucoma or ocular hypertension. Am J Ophthalmol. 2005; 140(2): $242-50$.

43. Sacchi M, Specchia C, Williams SE, Villani E, Nucci P. Efficacy of bimatoprost plus timolol fixed combination in open angle glaucoma patients previously treated with dorzolamide plus timolol fixed combination. Curr Eye Res. 2016; 41(11): 1433-7.

44. Konstas AG, Voudouragkaki IC, Boboridis KG, Haidich AB, Paschalinou E, Giannopoulos T, et al. 24-hour efficacy of travoprost/timolol BAK-free versus latanoprost/timolol fixed combinations in patients insufficiently controlled with latanoprost. Adv Ther. 2014; 31(6): 592-603.

45. Hartleben-Matkin C, Prada D, Mancilla-Vences R. A 4-year retrospective study of addon therapy to the fixed combination of dorzolamide/timolol for the treatment of POAG. Int J Ophthalmol. 2014; 7(2): 330-4.

46. Lesk MR, Koulis t, Sampalis F, Sampalis JS, Bastien NR. Effectiveness and safety of dorzolamide-timolol alone or combined with latanoprost in open-angle glaucoma or ocular hypertension. Ann Pharmacother. 2006; 42(4): 498-504.

47. Michaud JE, Friren B; International Brinzolamide Adjunctive Study Group. Comparison of topical brinzolamide $1 \%$ and dorzolamide $2 \%$ eye drops given twice daily in addition to timolol $0.5 \%$ in patients with primary open-angle glaucoma or ocular hypertension. Am J Ophthalmol. 2001; 132(2): 235-43. 
48. Solish AM, DeLucca PT, Cassel DA, Kolodny AH, Hustad CM, Skobieranda F. Dorzolamide/Timolol fixed combination versus concomitant administration of brimonidine and timolol in patients with elevated intraocular pressure: a 3-month comparison of efficacy, tolerability, and patient-reported measures. J Glaucoma. 2007; $2004 ; 13(2): 149-57$.

49. Greig SL, Deeks ED. Brinzolamide/brimonidine: a review of its use in patients with open-angle glaucoma or ocular hypertension. Drugs Aging. 2015; 32(3): 251-60.

50. Sharma S, Trikha S, Perera SA, Aung T. Clinical effectiveness of brinzolamide 1\%brimonidine $0.2 \%$ fixed combination for primary open-angle glaucoma and ocular hypertension. Clin Ophthalmol. 2015; 9: 2201-7.

51. The Glaucoma Laser Trial (GLT) and glaucoma laser trial follow-up study: 7. Results. Glaucoma Laser Trial Research Group. Am J Ophthalmol. 1995; 120(6): 718-31.

52. Rolim de Moura C, Paranhos A Jr, Wormald R. Laser trabeculoplasty for open angle glaucoma. Cochrane Database Syst Rev. 2007; (4): CD003919.

53. Spiegel D, Wetzel W, Neuhann T, Stuermer J, Hoeh H, Garcia-Feijoo J, et al. Coexistent primary open-angle glaucoma and cataract: interim analysis of a trabecular micro-bypass stent and concurrent cataract surgery. Eur J Ophthalmol. 2009; 19(3): 393-9.

54. Okeke CO, Quigley HA, Jampel HD, Ying GS, Plyler RJ, Jiang Y, Friedman DS. Interventions improve poor adherence with once daily glaucoma medications in electronically monitored patient. Ophthalmology. 2009; 116(12): 2289-93.

55. Gupta R, Patil B, Shah BM, Bali, Mishra SK, Dada T. Evaluating eye drop instillation technique in glaucoma patients. J Glaucoma. 2012; 21(3): 189-92. 
56. Campbell JH, Schwartz G, Labounty B, Kowalski J, Patel VD. Comparison of adherence and persistence with bimatoprost $0.01 \%$ versus bimatoprost $0.03 \%$ topical ophthalmic solutions. Curr Med Res Opin. 2013; 29(9): 1201-9.

57. Barnebey HS, Robin AL. Adherence to fixed-combination versus unfixed travoprost 0.004\%/timolol $0.5 \%$ for glaucoma or ocular hypertension: a randomized trial. Am J Ophthalmol. 2017; 176: 61-9.

58. Lee PP, Walt JG, Doyle JJ, Kotak SV, Evans SJ, Budenz DL, et al. A multicenter, retrospective pilot study of resource use and costs associated with severity of disease in glaucoma. Arch Ophthalmol. 2006; 124(1): 12-9.

59. Weinreb RN, Friedman DS, Fechtner DS, Fechtner RD, Cioffi GA, Coleman AL, Girkin CA, et al. Risk assessment in the management of patients with ocular hypertension. Am J Ophthalmol. 2004; 138(3): 458-67.

60. Lee BS, Kymes SM, Nease RF Jr, Sumner W, Siegfried CJ, Gordon MO. The impact of anchor points on utilities for 5 common ophthalmic diseases. Ophthalmology. 2008; 115(5): 898-903.

61. Katsoulis M, Benetou V, Karapetyan T, Feskanich D, Grodstein F, Pettersson-Kymmer U, et al. Excess mortality after hip fracture in elderly persons from Europe and the USA: the CHANCES project. J Intern Med. 2017; 281(13): 300-10.

62. Departamento Administrativo Nacional de Estadística (DANE). Proyecciones nacionales y departamentales de población 2005-2020. Bogotá D.C.: DANE, 2010.

63. Berdahl JP, Khatana AK, Katz LJ, Herndon L, Layton AJ, Yu TM, et al. Costcomparison of two trabecular micro-bypass stents versus selective laser trabeculoplasty 
or medication only for intraocular pressure control for patients with open-angle glaucoma. J Med Econ. 2017; 20(7): 760-6.

64. Pizzi LT, Waisbourd M, Hark L, Sembhi H, Lee P, Crews JE, et al. Costs of a community-based glaucoma detection programme: analysis of the Philadelphia Glaucoma Detection and Treatment Project. Br J Ophthalmol. 2017 Jun 27. pii: bjophthalmol-2016310078 .

65. Javanbakht M, Azuara-Blanco A, Burr JM, Ramsay C, Cooper D, Cochran C, et al. Early lens extraction with intraocular lens implantation for the treatment of primary angle closure glaucoma: an economic evaluation on data from the EAGLE trial. BMJ Open. 2017; 7(1): e013254.

66. Boodhna T, Crabb DP. More frequent, more costly? Health economic modelling aspects of monitoring glaucoma patients in England. BMC Health Serv Res. 2016; 16(1): 611.

67. Kaplan RI, De Moraes CG, Cioffi GA, Al-Aswad LA, Blumberg DM. Comparative costeffectiveness of the Baerveldt implant, trabeculectomy with mitomycin, and medical treatment. JAMA Ophthalmol. 2015; 133(5): 560-7.

68. Patel HY, Wagschal LD, Trope GE, Buys YM. Economic analysis of the Ex-PRESS miniature glaucoma device versus trabeculectomy. J Glaucoma. 2014; 23(6): 385-90. 


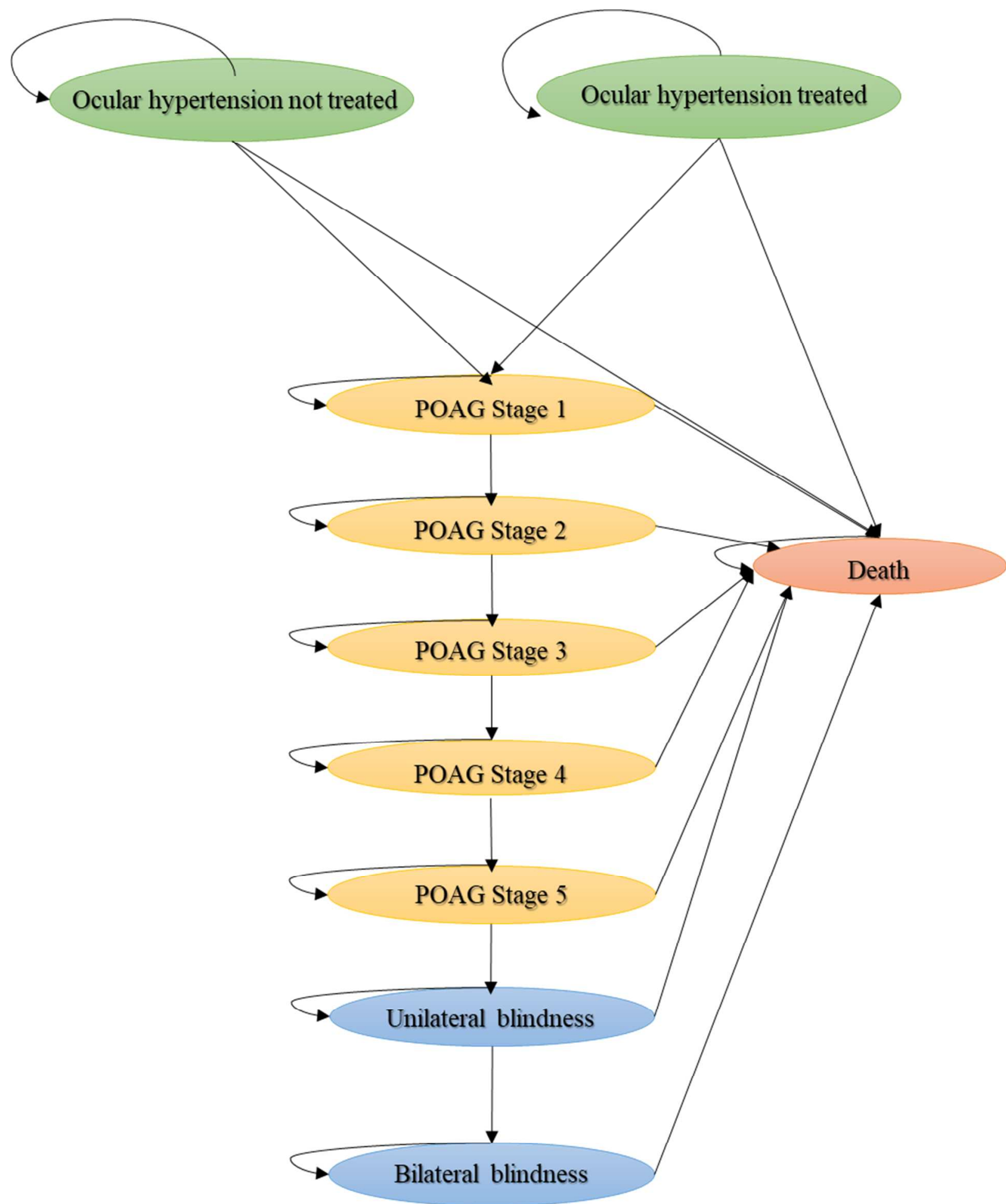

Figure 1. Structure of Markov decision model of patients with POAG during lifetime horizon, adapted from categorization of glaucoma natural history, by Mills et al (23). 
Figure 2. Diagram of tornado of micro-bypass trabecular stent versus selective laser trabeculoplasty for treatment of POAG in Colombia, 2018

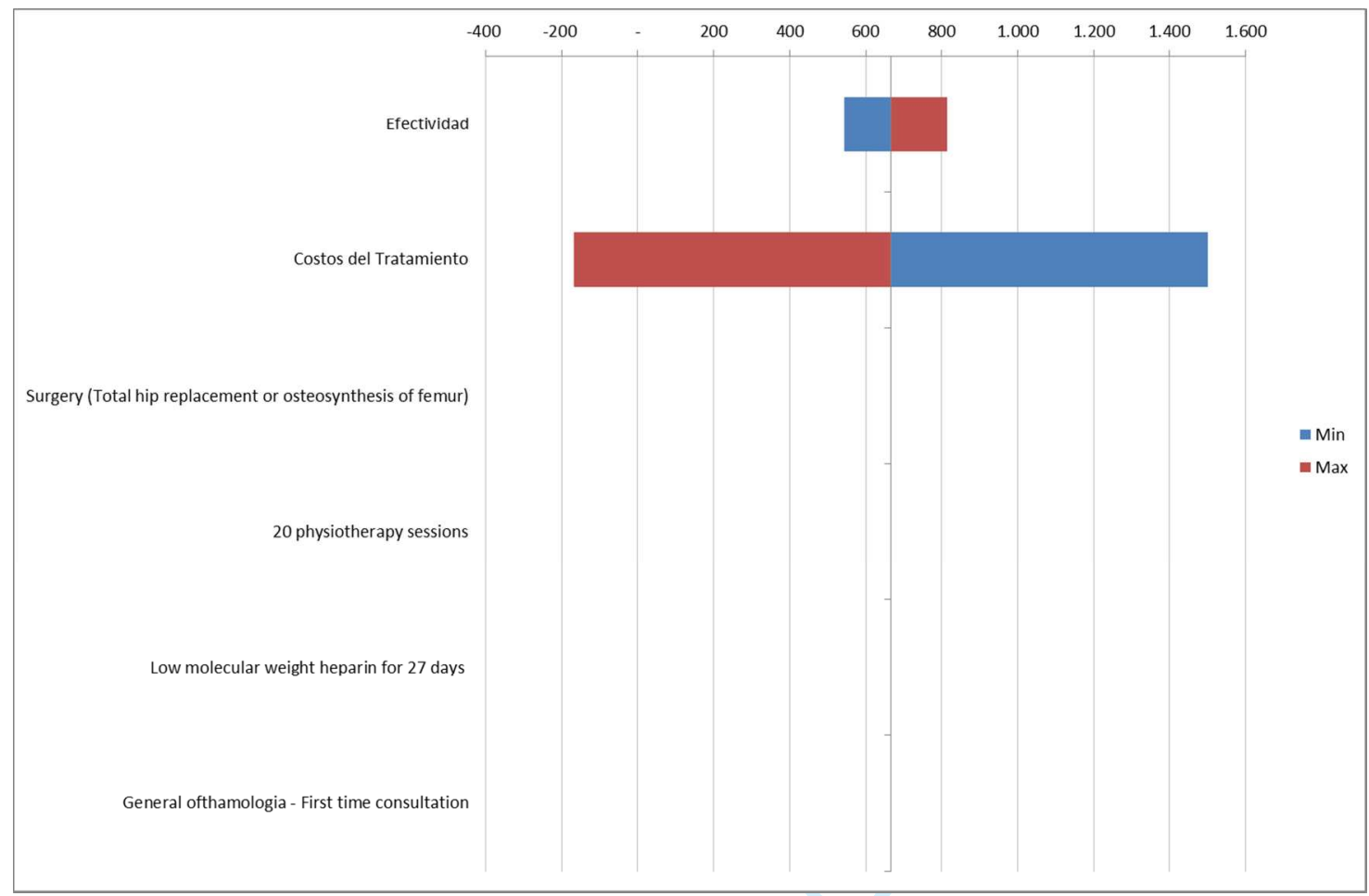


Figure 3. Diagram of tornado of micro-bypass trabecular stent versus medical treatment with latanoprost + timolol + dorzolamide for treatment of POAG in Colombia, 2018.

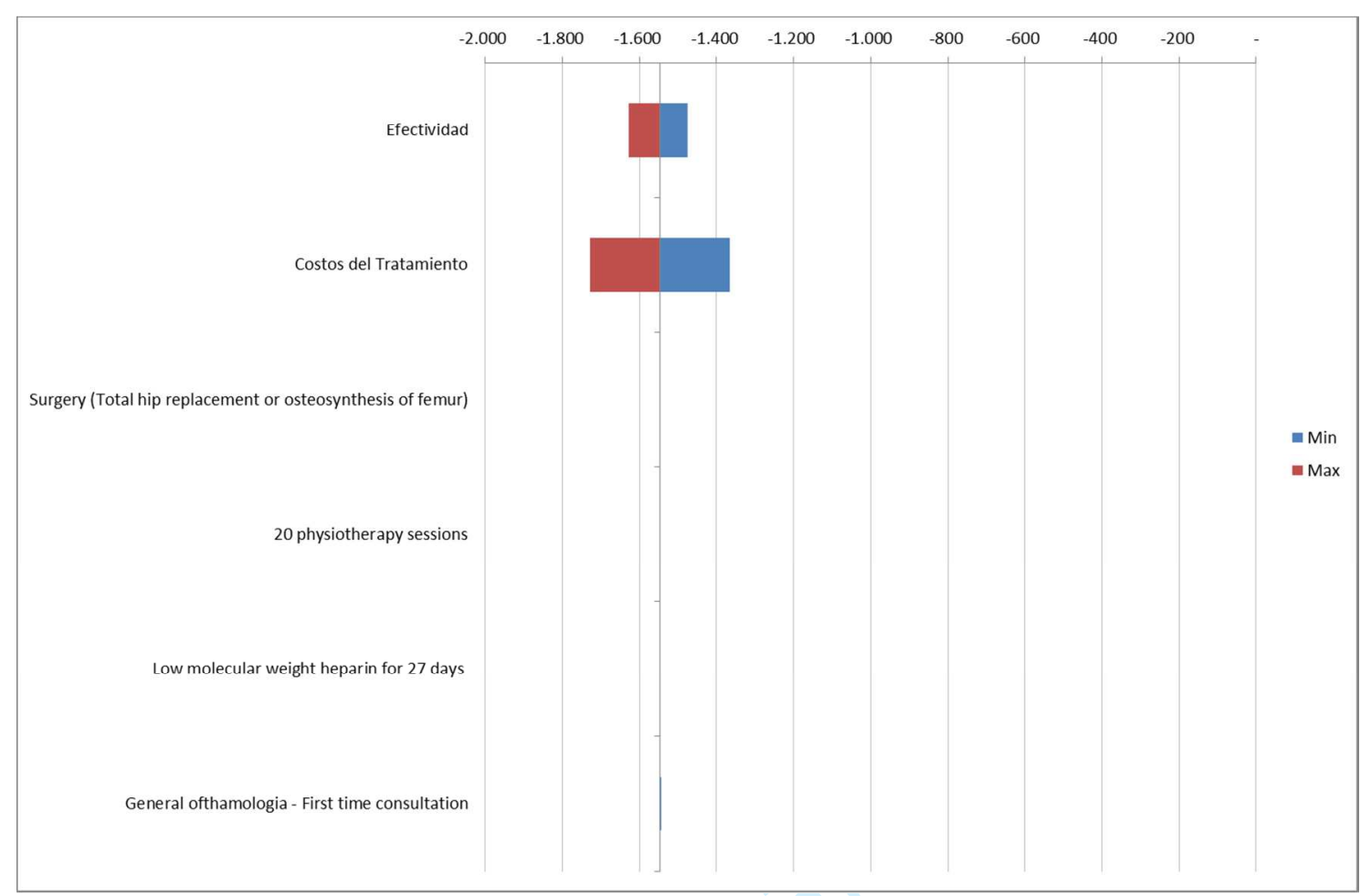


2

3

4

5

6

7

8

9

10

11

12

13

14

15

16

17

18

Figure 4. Diagram of tornado of micro-bypass trabecular stent versus medical treatment with bimatoprost + timolol + dorzolamide for treatment of POAG in Colombia, 2018.

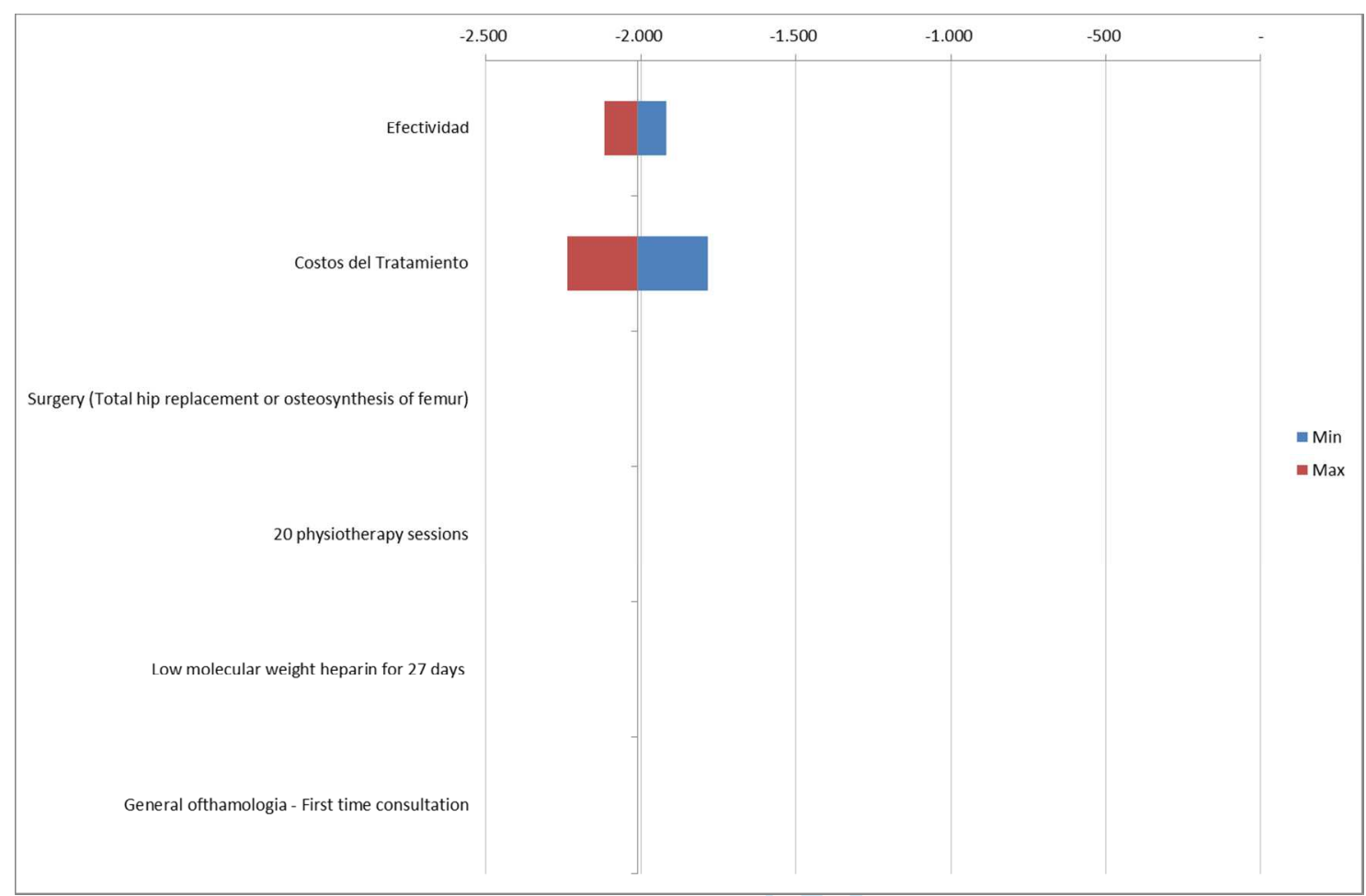


Figure 5. Diagram of tornado of micro-bypass trabecular stent versus medical treatment with travoprost + timolol + dorzolamide for treatment of POAG in Colombia, 2018.

\begin{tabular}{|r|r|r|r|r|r|r|r|r|}
\hline \\
Costos del Tratamiento
\end{tabular}


Figure 6. Diagram of tornado of micro-bypass trabecular stent versus medical treatment with brimonidine + timolol + dorzolamide for treatment of POAG in Colombia, 2018.

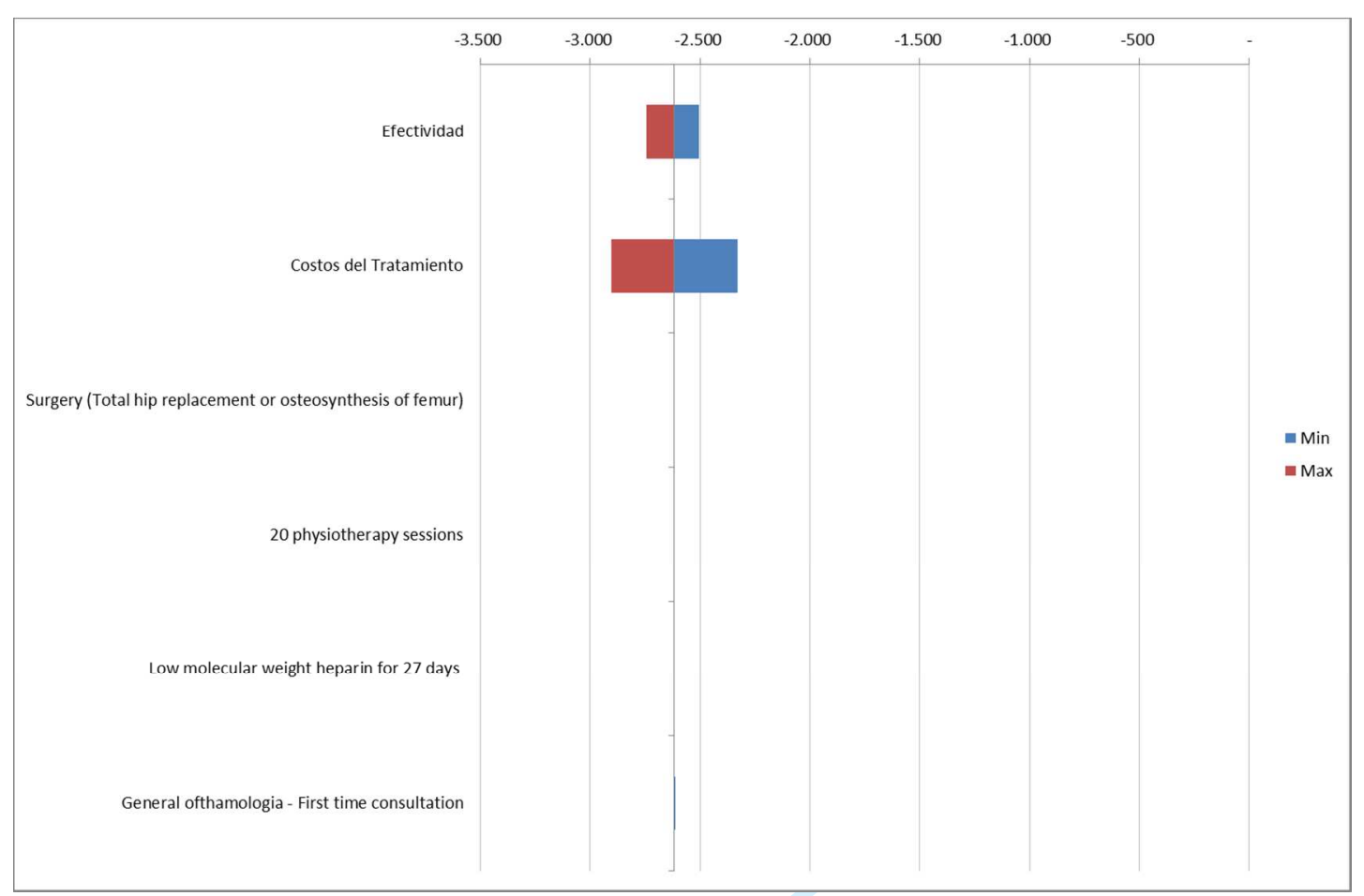


Figure 7. Diagram of tornado of micro-bypass trabecular stent versus medical treatment with timolol + travaprost for treatment of POAG in Colombia, 2018.

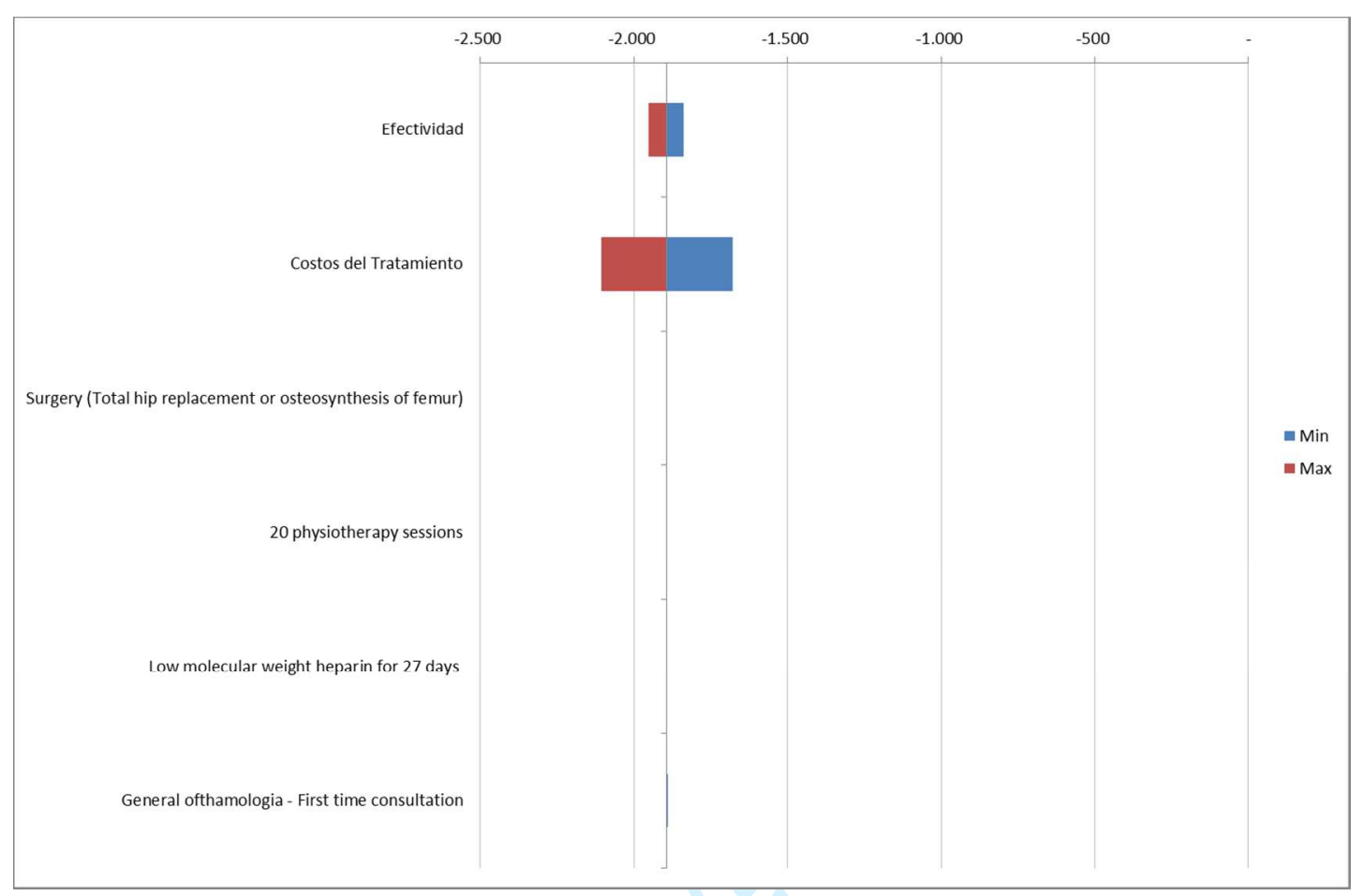


2

3

4

5

6

7

8

9

10

11

12

13

14

15

16

17

18

Figure 8. Diagram of tornado of micro-bypass trabecular stent versus medical treatment with timolol + travaprost (Bak Free) for treatment of POAG in Colombia, 2018.

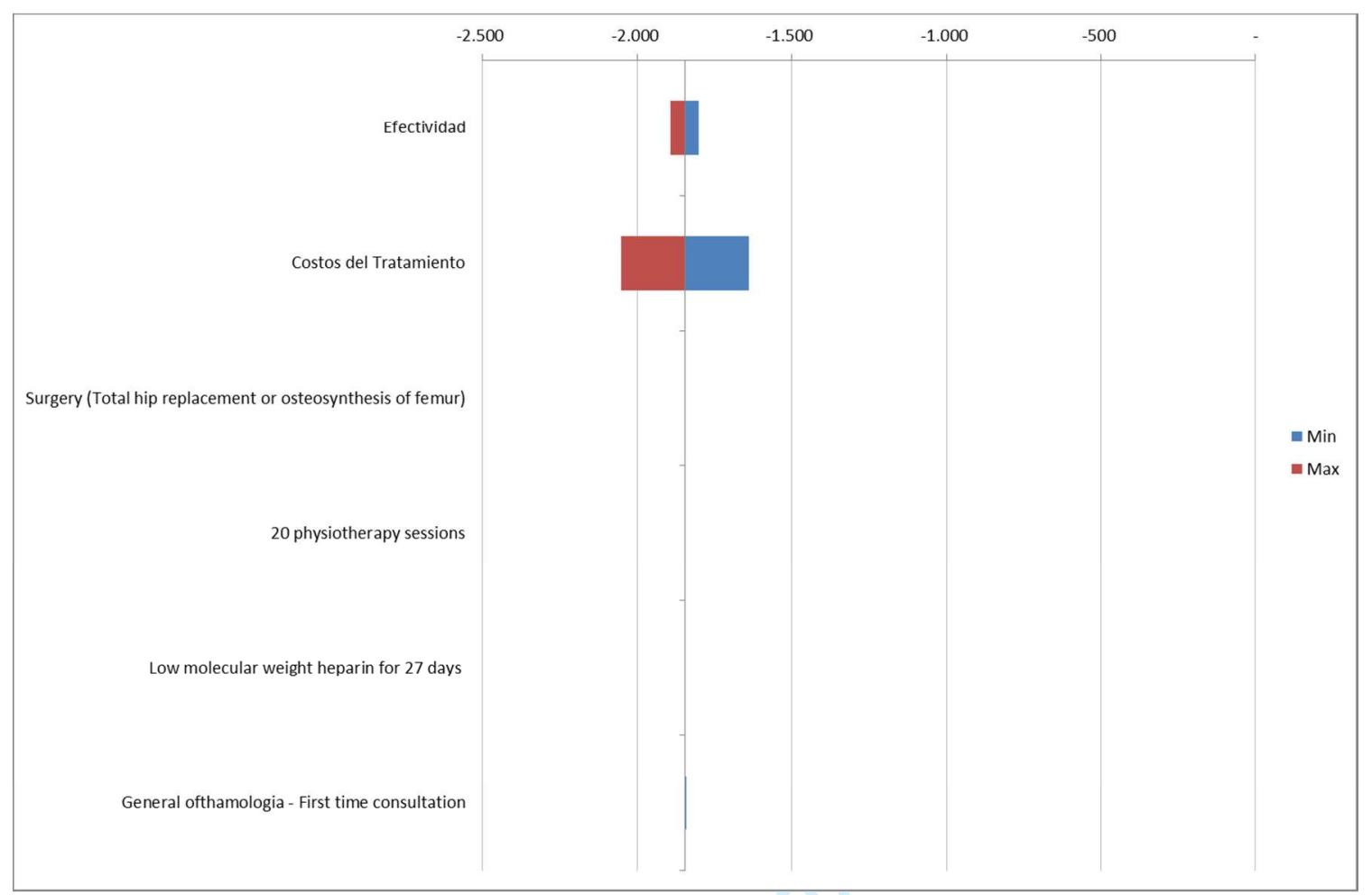


Figure 9. Diagram of tornado of micro-bypass trabecular stent versus medical treatment with timolol + brinzolamide for treatment of POAG in Colombia, 2018.

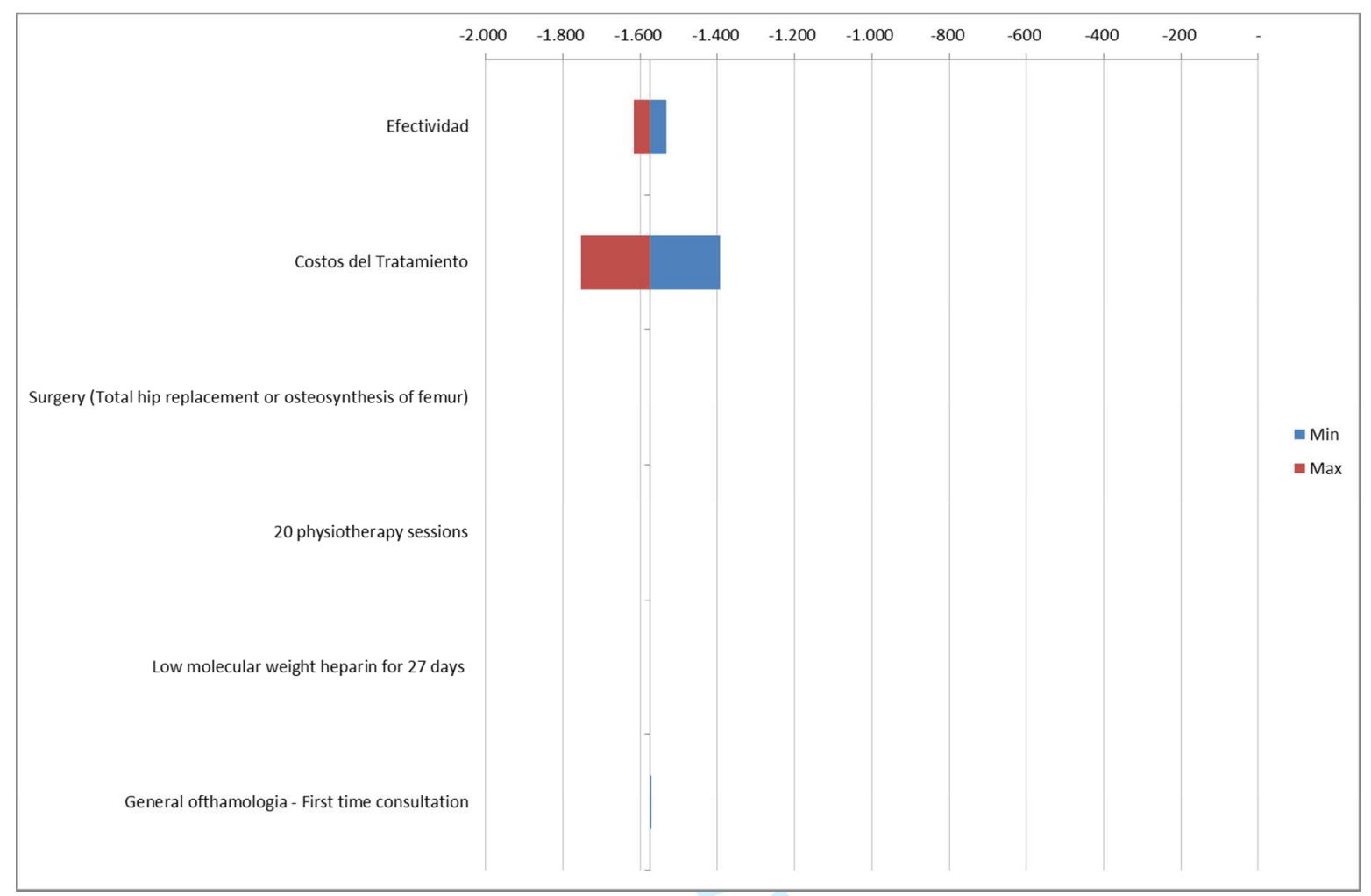


2

3

4

5

6

7

8

9

10

11

12

13

14

15

16

17

18

Figure 10. Diagram of tornado of micro-bypass trabecular stent versus medical treatment with timolol + brimonidine for treatment of POAG in Colombia, 2018.

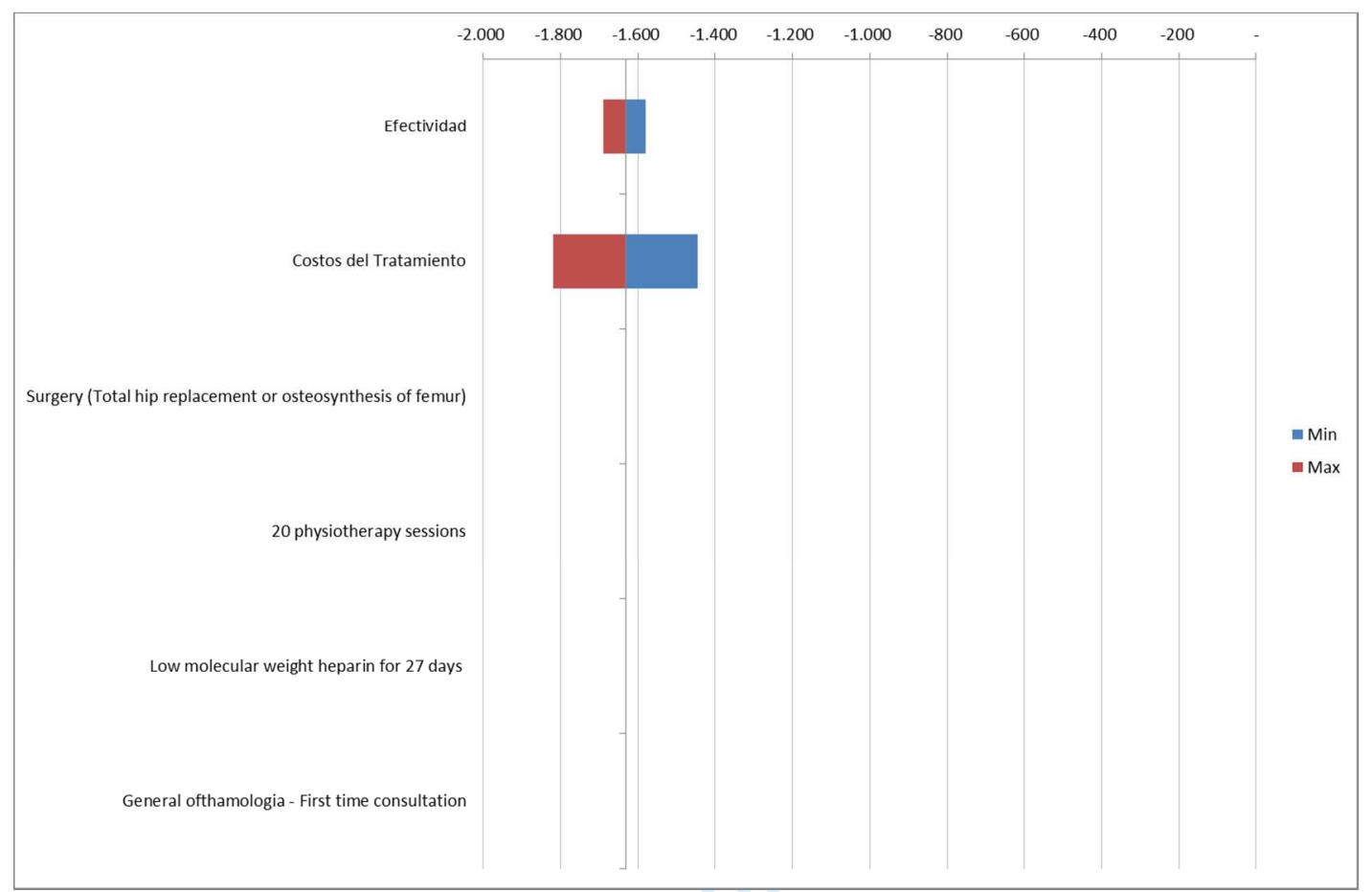


Figure 11. Diagram of tornado of micro-bypass trabecular stent versus medical treatment with brinzolamide + brimonidine for treatment of POAG in Colombia, 2018.

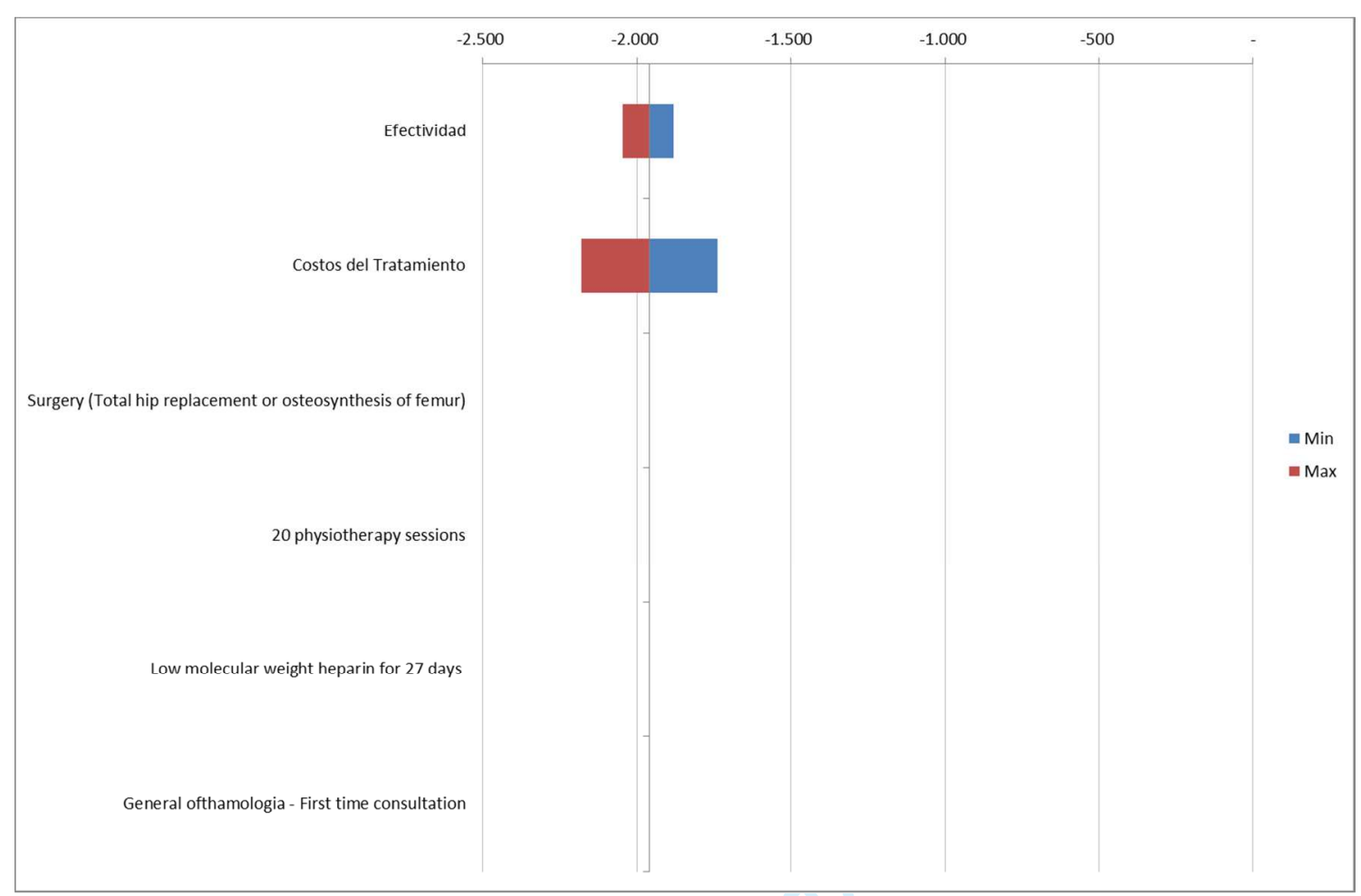


Figure 12. Cost-effectiveness plane of micro-bypass trabecular stent versus selective laser trabeculoplasty and each one of drug combinations used in Colombia for treatment of POAG, 2018.

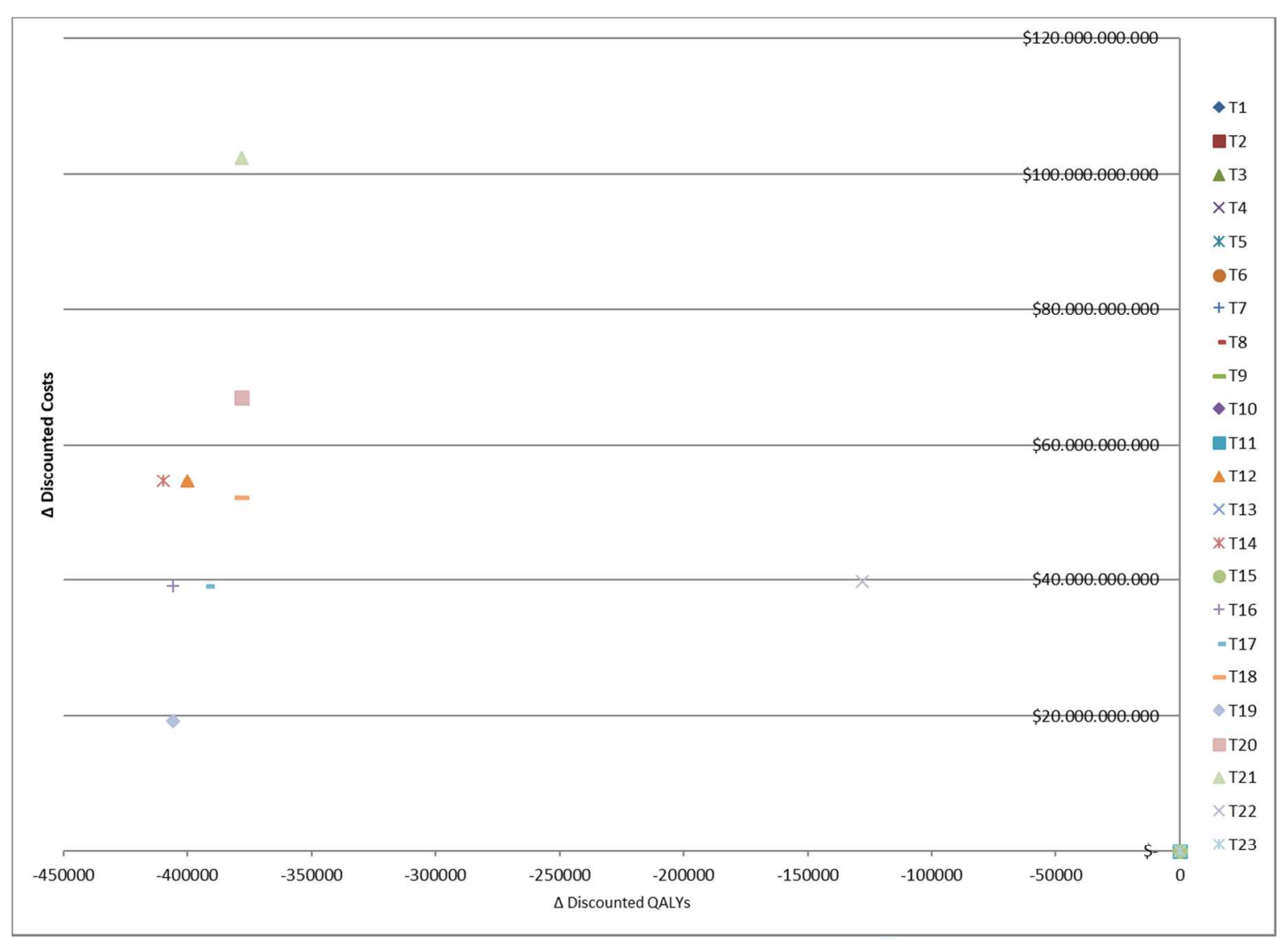

T23: micro-bypass trabecular stent / T22: selective laser trabeculoplasty

T21: travoprost + timolol + dorzolamide / T20: latanoprost + timolol + dorzolamide

T19: brimonidina + timolol + dorzolamide / T12: travaprost + timolol

T14: travaprost + timolol (Bak Free) / T16: timolol + brinzolamide

T17: timolol + brimonidine / T18: brinzolamide + brimonidine 
Figure 13. Willingness-to-pay curves of the micro-bypass trabecular stent versus selective laser trabeculoplasty and each one of drug combinations used in Colombia for treatment of POAG, 2018.

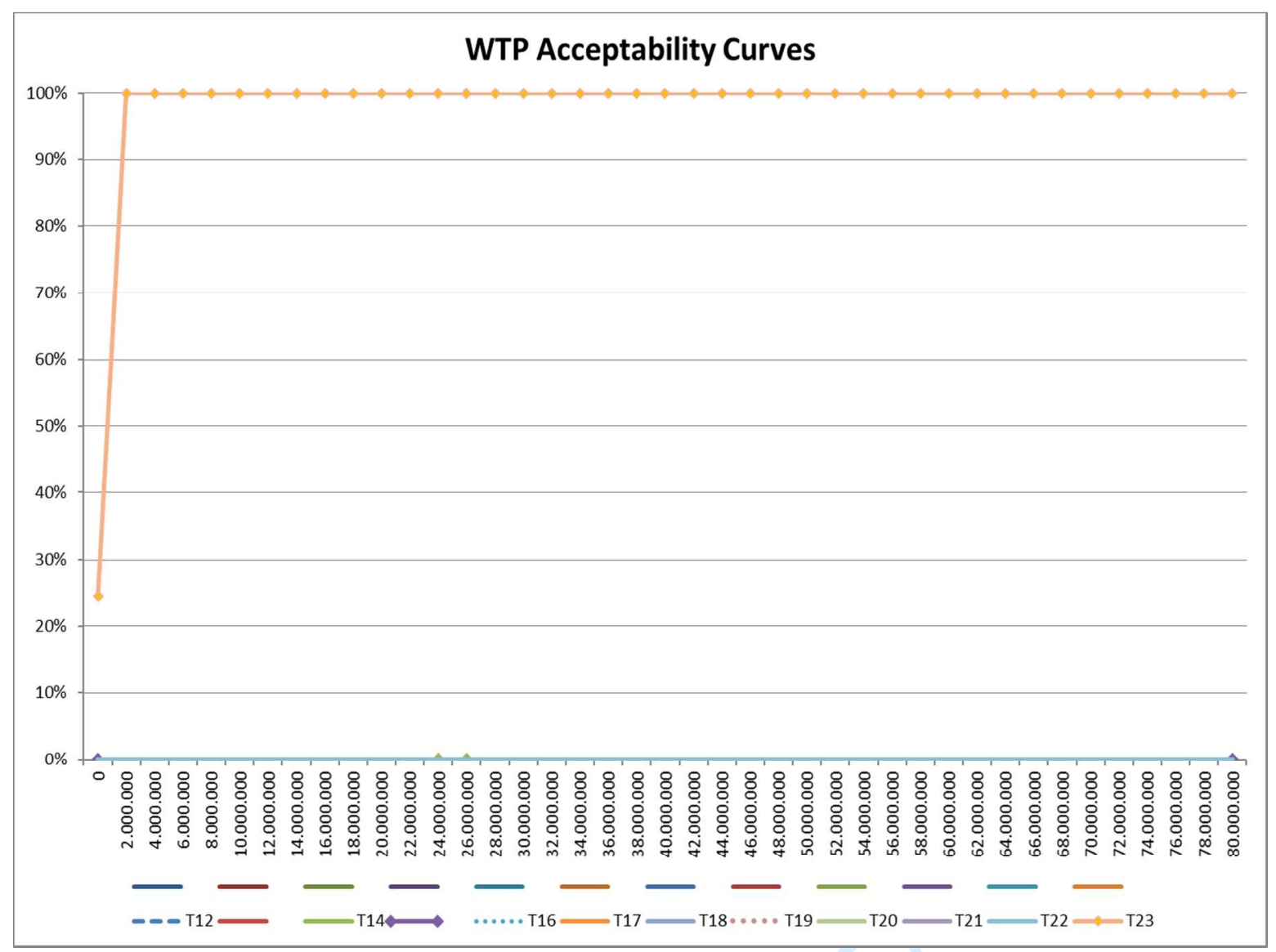

T23: micro-bypass trabecular stent / T22: selective laser trabeculoplasty

T21: travoprost + timolol + dorzolamide / T20: latanoprost + timolol + dorzolamide

T19: brimonidina + timolol + dorzolamide / T12: travaprost + timolol

T14: travaprost + timolol (Bak Free) / T16: timolol + brinzolamide

T17: timolol + brimonidine / T18: brinzolamide + brimonidine 
Table 1. Weighted costs of drugs for ocular hypertension treatment, according to information from SISMED database in Colombia, during 2017.

\begin{tabular}{|l|c|}
\hline \multicolumn{1}{|c|}{ Medicine } & Annual weighted mean cost (USD) \\
\hline Latanoprost & $\$ 258.57$ \\
\hline Travoprost & $\$ 385.45$ \\
\hline Bimatroprost & $\$ 332.13$ \\
\hline Tafluprost & $\$ 184.84$ \\
\hline Timolol & $\$ 28.15$ \\
\hline Betaxolol & $\$ 280.30$ \\
\hline Brimonidine & $\$ 356.59$ \\
\hline Dorzolamide & $\$ 232.74$ \\
\hline Brinzolamide & $\$ 316.43$ \\
\hline Pilocarpine & $\$ 67.64$ \\
\hline Latanoprost + Timolol & $\$ 81.19$ \\
\hline Travaprost + Timolol & $\$ 406.90$ \\
\hline Bimatoprost + Timolol & $\$ 162.00$ \\
\hline Travaprost + Timolol (Bak Free) & $\$ 406.90$ \\
\hline Dorzolamide + Timolol & $\$ 191.92$ \\
\hline Brinzolamide + Timolol & $\$ 350.53$ \\
\hline Brimonidine + Timolol & $\$ 350.53$ \\
\hline Brinzolamide + Brimonidine & $\$ 279.54$ \\
\hline Dorzolamide + Brimonidine + Timolol & \\
\hline Enoxaparin (27 days) & \\
\hline
\end{tabular}


Table 2. Prevalence of glaucoma in Colombia according to age groups [8].

\begin{tabular}{|c|c|}
\hline Age group & Prevalence of glaucoma \\
\hline $\mathbf{4 0}-\mathbf{4 4}$ years & $0.07 \%$ \\
\hline $\mathbf{4 5}-\mathbf{4 9}$ years & $0.12 \%$ \\
\hline $\mathbf{5 0}-\mathbf{5 4}$ years & $0.20 \%$ \\
\hline $\mathbf{5 5}-\mathbf{5 9}$ years & $0.30 \%$ \\
\hline $\mathbf{6 0}-\mathbf{6 4}$ years & $0.47 \%$ \\
\hline $\mathbf{7 0}-\mathbf{6 4}$ years & $0.65 \%$ \\
\hline $\mathbf{7 5}-\mathbf{7 9}$ years & $0.86 \%$ \\
\hline & \\
\hline & \\
\hline
\end{tabular}


Table 3. Clinical efficacy (mean, minimum and maximum values) of strategies available in Colombia for glaucoma treatment.

\begin{tabular}{|c|c|c|c|c|}
\hline Treatment strategy & Mean value & Minimum & Maximum & Sources \\
\hline Latanoprost & $32 \%$ & $27 \%$ & $37 \%$ & {$[33,34]$} \\
\hline Travoprost & $33 \%$ & $28 \%$ & $38 \%$ & {$[33,34]$} \\
\hline Bimatoprost & $40 \%$ & $34 \%$ & $46 \%$ & {$[33,34]$} \\
\hline Tafluprost & $27 \%$ & $23 \%$ & $31 \%$ & [34] \\
\hline Timolol & $48 \%$ & $41 \%$ & $55 \%$ & {$[33,35]$} \\
\hline Betaxolol & $20 \%$ & $17 \%$ & $23 \%$ & {$[33]$} \\
\hline Brimonidine & $24 \%$ & $20 \%$ & $28 \%$ & {$[33,36]$} \\
\hline Dorzolamide & $55 \%$ & $47 \%$ & $63 \%$ & {$[33,37]$} \\
\hline Brinzolamide & $52 \%$ & $44 \%$ & $60 \%$ & {$[33,37]$} \\
\hline Pilocarpine & $17 \%$ & $14 \%$ & $20 \%$ & {$[38]$} \\
\hline Latanoprost + Timolol & $50 \%$ & $43 \%$ & $58 \%$ & {$[39,40]$} \\
\hline Travoprost + Timolol & $38 \%$ & $32 \%$ & $44 \%$ & {$[51,52]$} \\
\hline Bimatroprost + Timolol & $55 \%$ & $47 \%$ & $63 \%$ & {$[35,43]$} \\
\hline Travoprost + Timolol [Bak Free] & $33 \%$ & $28 \%$ & $38 \%$ & {$[44]$} \\
\hline Timolol + Dorzolamide & $49 \%$ & $42 \%$ & $56 \%$ & {$[45,46]$} \\
\hline
\end{tabular}




\begin{tabular}{|l|c|c|c|c|}
\hline \multicolumn{1}{|c|}{ Treatment strategy } & Mean value & Minimum & Maximum & Sources \\
\hline Timolol + Brinzolamide & $35 \%$ & $30 \%$ & $40 \%$ & {$[47]$} \\
\hline Timolol + Brimonidine & $42 \%$ & $36 \%$ & $48 \%$ & {$[36,48]$} \\
\hline Brinzolamide + Brimonidine & $49 \%$ & $42 \%$ & $56 \%$ & {$[49,50]$} \\
\hline Timolol + Dorzolamide + Brimonidine & $35 \%$ & $30 \%$ & $40 \%$ & {$[45]$} \\
\hline Laser surgery with argon & $20 \%$ & $9 \%$ & $29 \%$ & {$[51,52]$} \\
\hline iStent ${ }^{\mid}$+ MIGS & $69,1 \%$ & $58,7 \%$ & $79,5 \%$ & {$[53]$} \\
\hline
\end{tabular}


Table 4. Transition probabilities between different stages of glaucoma.

\begin{tabular}{|c|c|c|c|c|c|c|c|}
\hline $\begin{array}{c}\text { Clinical stages of } \\
\text { glaucoma }\end{array}$ & 1 & 2 & 3 & 4 & 5 & $\begin{array}{l}\text { Unilateral } \\
\text { blindness }\end{array}$ & $\begin{array}{l}\text { Bilateral } \\
\text { blindness }\end{array}$ \\
\hline 1 & 0.938 & 0.062 & 0.000 & 0.000 & 0.000 & 0.000 & 0.000 \\
\hline 2 & 0.000 & 0.950 & 0.050 & 0.000 & 0.000 & 0.000 & 0.000 \\
\hline 3 & 0.000 & 0.000 & 0.946 & 0.054 & 0.000 & 0.000 & 0.000 \\
\hline 4 & 0.000 & 0.000 & 0.000 & 0.940 & 0.060 & 0.000 & 0.000 \\
\hline 5 & 0.000 & 0.000 & 0.000 & 0.000 & 0.095 & 0.050 & 0.000 \\
\hline Unilateral blindness & 0.000 & 0.000 & 0.000 & 0.000 & 0.000 & 0.973 & 0.027 \\
\hline
\end{tabular}


Table 5. QALY in patients with glaucoma according to level of disease severity.

\begin{tabular}{|l|c|c|c|c|}
\hline \multicolumn{1}{|c|}{ Severity of the disease } & Stage of glaucoma & Mean QALY & Minimum & Maximum \\
\hline Mild & Stage 1 & 0.92 & 0.87 & 0.97 \\
\hline \multirow{2}{*}{ Moderate } & Stage 2 & 0.90 & 0.86 & 0.95 \\
\cline { 2 - 5 } & Stage 3 & 0.90 & 0.86 & 0.95 \\
\hline \multirow{2}{*}{ Severe } & Stage 4 & 0.76 & 0.72 & 0.80 \\
& Stage 5 & 0.76 & 0.72 & 0.80 \\
\hline Unilateral blindness & & 0.76 & 0.72 & 0.80 \\
\hline Bilateral blindness & & & & \\
\hline
\end{tabular}


Table 6. Risk ratio (RR) of having a hip fracture in older adults with glaucoma, according to disease clinical stage [29].

\begin{tabular}{|c|c|}
\hline Stage of glaucoma & Risk ratio (RR) \\
\hline Ocular hypertension without glaucoma & 1.00 \\
\hline $\mathbf{1}$ & 1.25 \\
\hline $\mathbf{3}$ & 1.49 \\
\hline $\mathbf{4}$ & 1.49 \\
\hline $\mathbf{5}$ & 1.74 \\
\hline Unilateral blindness & 1.74 \\
\hline Bilateral blindness & 1.74 \\
\hline
\end{tabular}


Table 7. Excess mortality by hip fracture in older adults, according to time elapsed after fracture, expressed as Hazard Ratio (HR) [61].

\begin{tabular}{|l|c|}
\hline Time since fracture & Hazard Ratio (HR) \\
\hline$<1$ year & 2.78 \\
\hline $1-3$ years & 1.89 \\
\hline $4-7$ years & 2.15 \\
\hline$\geq 8$ years & 1.79 \\
\hline
\end{tabular}


Table 8. Deterministic results of micro-bypass trabecular stent versus the laser selective trabeculoplasty surgery and the different combinations of drugs for ocular hypertension treatment (discount rate: $5 \%$ ).

\begin{tabular}{|c|c|c|c|c|c|}
\hline Strategies & $\begin{array}{c}\text { Discounted } \\
\text { total cost } \\
\text { (USD) }\end{array}$ & $\begin{array}{c}\text { Incremental } \\
\text { discounted total } \\
\text { cost (USD) }\end{array}$ & $\begin{array}{c}\text { Discounted } \\
\text { QALYs }\end{array}$ & $\begin{array}{c}\text { Incremental } \\
\text { discounted } \\
\text { QALYs }\end{array}$ & $\begin{array}{l}\text { ICER } \\
\text { (USD) }\end{array}$ \\
\hline $\begin{array}{l}\text { Micro-bypass trabecular } \\
\text { stent }+ \text { Timolol }\end{array}$ & $\$ 22,018,777$ & & $2,226,612$ & & \\
\hline $\begin{array}{l}\text { Laser selective } \\
\text { trabeculoplasty }+ \text { Timolol }+ \\
\text { Dorzolamida }\end{array}$ & $\$ 35,272,096$ & $-(\$ 13,253,318)$ & $2,098,641$ & 127,971 & $-(\$ 104)$ \\
\hline $\begin{array}{l}\text { Latanoprost + Timolol + } \\
\text { Dorzolamide }\end{array}$ & $\$ 44,329,841$ & $-(\$ 22,311,064)$ & $1,848,325$ & 378,287 & $-(\$ 59)$ \\
\hline $\begin{array}{l}\text { Bimatoprost + Timolol + } \\
\text { Dorzolamide }\end{array}$ & $\$ 51,174,890$ & $-(\$ 29,156,113)$ & $1,848,325$ & 378,287 & $-(\$ 77)$ \\
\hline $\begin{array}{l}\text { Travoprost + Timolol + } \\
\text { Dorzolamide }\end{array}$ & $\$ 56,135,683$ & $-(\$ 34,116,906)$ & $1,848,325$ & 378,287 & $-(\$ 90)$ \\
\hline $\begin{array}{l}\text { Brimonidine }+ \text { Timolol }+ \\
\text { Dorzolamide }\end{array}$ & $\$ 28,422,312$ & $-(\$ 6,403,534)$ & $1,820,630$ & 405,982 & $-(\$ 16)$ \\
\hline Timolol + Travaprost & $\$ 40,273,428$ & $-(\$ 18,254,651)$ & $1,826,464$ & 400,148 & $-(\$ 46)$ \\
\hline
\end{tabular}




\begin{tabular}{|c|c|c|c|c|c|}
\hline Strategies & $\begin{array}{c}\text { Discounted } \\
\text { total cost } \\
\text { (USD) }\end{array}$ & $\begin{array}{c}\text { Incremental } \\
\text { discounted total } \\
\text { cost (USD) }\end{array}$ & $\begin{array}{l}\text { Discounted } \\
\text { QALYs }\end{array}$ & $\begin{array}{c}\text { Incremental } \\
\text { discounted } \\
\text { QALYs }\end{array}$ & $\begin{array}{l}\text { ICER } \\
\text { (USD) }\end{array}$ \\
\hline $\begin{array}{l}\text { Timolol + Travaprost (Bak } \\
\text { Free) }\end{array}$ & $\$ 40,273,420$ & $-(\$ 18,254,643)$ & $1,816,769$ & 409,842 & $-(\$ 45)$ \\
\hline Timolol + Brinzolamide & $\$ 35,028,573$ & $-(\$ 13,009,796)$ & $1,820,630$ & 405,982 & $-(\$ 32)$ \\
\hline Timolol + Brimonidine & $\$ 35,028,583$ & $-(\$ 13,009,805)$ & $1,834,325$ & 392,286 & $-(\$ 33)$ \\
\hline $\begin{array}{l}\text { Brimonidine }+ \\
\text { Brinzolamide }\end{array}$ & $\$ 39,439,894$ & $-(\$ 17,421,116)$ & $1,848,325$ & 378,287 & $-(\$ 46)$ \\
\hline
\end{tabular}


Table 9. Deterministic results of micro-bypass trabecular stent versus the laser selective trabeculoplasty surgery and the different combinations of drugs for ocular hypertension treatment (discount rate: $3,5 \%$ ).

\begin{tabular}{|c|c|c|c|c|c|}
\hline Strategies & $\begin{array}{c}\text { Discounted } \\
\text { total cost } \\
\text { (USD) }\end{array}$ & $\begin{array}{c}\text { Incremental } \\
\text { discounted total } \\
\text { cost (USD) }\end{array}$ & $\begin{array}{c}\text { Discounted } \\
\text { QALYs }\end{array}$ & $\begin{array}{c}\text { Incremental } \\
\text { discounted } \\
\text { QALYs }\end{array}$ & $\begin{array}{l}\text { ICER } \\
\text { (USD) }\end{array}$ \\
\hline $\begin{array}{l}\text { Micro-bypass trabecular } \\
\text { stent }+ \text { Timolol }\end{array}$ & $\$ 22,552,209$ & & $2,382,719$ & & \\
\hline $\begin{array}{l}\text { Laser selective } \\
\text { trabeculoplasty }+ \text { Timolol }+ \\
\text { Dorzolamida }\end{array}$ & $\$ 38,315,651$ & $-(\$ 15,763,442)$ & $2,246,023$ & 136,696 & $-(\$ 115)$ \\
\hline $\begin{array}{l}\text { Latanoprost + Timolol + } \\
\text { Dorzolamide }\end{array}$ & $\$ 48,485,493$ & $-(\$ 25,933,284)$ & $1,983,242$ & 399,477 & $-(\$ 65)$ \\
\hline $\begin{array}{l}\text { Bimatoprost + Timolol + } \\
\text { Dorzolamide }\end{array}$ & $\$ 55,972,238$ & $-(\$ 33,420,028)$ & $1,983,242$ & 399,477 & $-(\$ 84)$ \\
\hline $\begin{array}{l}\text { Travoprost + Timolol + } \\
\text { Dorzolamide }\end{array}$ & $\$ 61,398,085$ & $-(\$ 38,845,875)$ & $1,983,242$ & 399,477 & $-(\$ 97)$ \\
\hline $\begin{array}{l}\text { Brimonidine }+ \text { Timolol }+ \\
\text { Dorzolamide }\end{array}$ & $\$ 31,086,696$ & $-(\$ 8,534,487)$ & $1,953,680$ & 429,039 & $-(\$ 20)$ \\
\hline Timolol + Travaprost & $\$ 44,048,806$ & $-(\$ 21,496,596)$ & $1,959,910$ & 422,809 & $-(\$ 51)$ \\
\hline
\end{tabular}




\begin{tabular}{|c|c|c|c|c|c|}
\hline Strategies & $\begin{array}{c}\text { Discounted } \\
\text { total cost } \\
\text { (USD) }\end{array}$ & $\begin{array}{c}\text { Incremental } \\
\text { discounted total } \\
\text { cost (USD) }\end{array}$ & $\begin{array}{l}\text { Discounted } \\
\text { QALYs }\end{array}$ & $\begin{array}{c}\text { Incremental } \\
\text { discounted } \\
\text { QALYs }\end{array}$ & $\begin{array}{l}\text { ICER } \\
\text { (USD) }\end{array}$ \\
\hline $\begin{array}{l}\text { Timolol + Travaprost (Bak } \\
\text { Free) }\end{array}$ & $\$ 44,048,796$ & $-(\$ 21,496,587)$ & $1,949,557$ & 433,162 & $-(\$ 50)$ \\
\hline Timolol + Brinzolamide & $\$ 38,312,267$ & $-(\$ 15,760,057)$ & $1,953,680$ & 429,039 & $-(\$ 37)$ \\
\hline Timolol + Brimonidine & $\$ 38,312,279$ & $-(\$ 15,760,069)$ & $1,968,303$ & 414,416 & $-(\$ 38)$ \\
\hline $\begin{array}{l}\text { Brimonidine }+ \\
\text { Brinzolamide }\end{array}$ & $\$ 43,137,133$ & $-(\$ 20,584,924)$ & $1,983,242$ & 399,477 & $-(\$ 52)$ \\
\hline
\end{tabular}


Table 10. Deterministic results of micro-bypass trabecular stent versus the laser selective trabeculoplasty surgery and the different combinations of drugs for ocular hypertension treatment (discount rate: $10 \%$ ).

\begin{tabular}{|c|c|c|c|c|c|}
\hline Strategies & $\begin{array}{c}\text { Discounted } \\
\text { total cost } \\
\text { (USD) }\end{array}$ & $\begin{array}{c}\text { Incremental } \\
\text { discounted total } \\
\text { cost (USD) }\end{array}$ & $\begin{array}{l}\text { Discounted } \\
\text { QALYs }\end{array}$ & $\begin{array}{c}\text { Incremental } \\
\text { discounted } \\
\text { QALYs }\end{array}$ & $\begin{array}{l}\text { ICER } \\
\text { (USD) }\end{array}$ \\
\hline $\begin{array}{l}\text { Micro-bypass trabecular } \\
\text { stent }+ \text { Timolol }\end{array}$ & $\$ 20,929,951$ & & $2,057,194$ & & \\
\hline $\begin{array}{l}\text { Laser selective } \\
\text { trabeculoplasty }+ \text { Timolol }+ \\
\text { Dorzolamida }\end{array}$ & $\$ 28,238,466$ & $-(\$ 7,308,515)$ & $1,938,692$ & 118,502 & $-(\$ 62)$ \\
\hline $\begin{array}{l}\text { Latanoprost + Timolol + } \\
\text { Dorzolamide }\end{array}$ & $\$ 34,716,334$ & $-(\$ 13,786,383)$ & $1,701,904$ & 355,290 & $-(\$ 39)$ \\
\hline $\begin{array}{l}\text { Bimatoprost + Timolol + } \\
\text { Dorzolamide }\end{array}$ & $\$ 40,076,914$ & $-(\$ 19,146,963)$ & $1,701,904$ & 355,290 & $-(\$ 54)$ \\
\hline $\begin{array}{l}\text { Travoprost + Timolol + } \\
\text { Dorzolamide }\end{array}$ & $\$ 43,961,871$ & $-(\$ 23,031,920)$ & $1,701,904$ & 355,290 & $-(\$ 65)$ \\
\hline $\begin{array}{l}\text { Brimonidine }+ \text { Timolol }+ \\
\text { Dorzolamide }\end{array}$ & $\$ 22,258,637$ & $-(\$ 1,328,686)$ & $1,676,235$ & 380,959 & $-(\$ 3)$ \\
\hline Timolol + Travaprost & $\$ 31,539,630$ & $-(\$ 10,609,679)$ & $1,681,639$ & 375,555 & $-(\$ 28)$ \\
\hline
\end{tabular}




\begin{tabular}{|c|c|c|c|c|c|}
\hline Strategies & $\begin{array}{c}\text { Discounted } \\
\text { total cost } \\
\text { (USD) }\end{array}$ & $\begin{array}{c}\text { Incremental } \\
\text { discounted total } \\
\text { cost (USD) }\end{array}$ & $\begin{array}{l}\text { Discounted } \\
\text { QALYs }\end{array}$ & $\begin{array}{c}\text { Incremental } \\
\text { discounted } \\
\text { QALYs }\end{array}$ & $\begin{array}{l}\text { ICER } \\
\text { (USD) }\end{array}$ \\
\hline $\begin{array}{l}\text { Timolol + Travaprost (Bak } \\
\text { Free) }\end{array}$ & $\$ 31,539,626$ & $-(\$ 10,609,675)$ & $1,672,660$ & 384,534 & $-(\$ 28)$ \\
\hline Timolol + Brinzolamide & $\$ 27,432,215$ & $-(\$ 6,502,264)$ & $1,676,235$ & 380,959 & $-(\$ 17)$ \\
\hline Timolol + Brimonidine & $\$ 27,432,220$ & $-(\$ 6,502,269)$ & $1,688,925$ & 368,269 & $-(\$ 18)$ \\
\hline $\begin{array}{l}\text { Brimonidine }+ \\
\text { Brinzolamide }\end{array}$ & $\$ 30,886,859$ & $-(\$ 9,956,908)$ & $1,701,904$ & 355,290 & $-(\$ 28)$ \\
\hline
\end{tabular}


Table 11. One-way sensitive analysis of micro-bypass trabecular stent versus the laser selective trabeculoplasty surgery and the different drugs combinations for ocular hypertension treatment, adjusted by minimum and maximum effectiveness.

\begin{tabular}{|c|c|c|c|c|c|}
\hline $\begin{array}{c}\text { Mean } \\
\text { effectiveness }\end{array}$ & $\begin{array}{l}\text { ICER of the } \\
\text { base case } \\
\text { (USD) }\end{array}$ & $\begin{array}{l}\text { Minimum } \\
\text { effectiveness }\end{array}$ & $\begin{array}{l}\text { ICER } \\
\text { (USD) }\end{array}$ & $\begin{array}{l}\text { Maximum } \\
\text { effectiveness }\end{array}$ & $\begin{array}{l}\text { ICER } \\
\text { (USD) }\end{array}$ \\
\hline $69.1 \%$ & & $58.7 \%$ & & $79.5 \%$ & \\
\hline $24.5 \%$ & $-\$ 104$ & $20.8 \%$ & $-\$ 96$ & $29.0 \%$ & $-\$ 115$ \\
\hline $24.5 \%$ & $-\$ 59$ & $20.8 \%$ & $-\$ 57$ & $28.2 \%$ & $-\$ 61$ \\
\hline $24.5 \%$ & $-\$ 77$ & $20.8 \%$ & $-\$ 87$ & $28.2 \%$ & $-\$ 94$ \\
\hline $24.5 \%$ & $-\$ 90$ & $20.8 \%$ & $-\$ 87$ & $28.2 \%$ & $-\$ 94$ \\
\hline $17.5 \%$ & $-\$ 16$ & $14.9 \%$ & $-\$ 15$ & $20.1 \%$ & $-\$ 16$ \\
\hline $19.0 \%$ & $-\$ 46$ & $16.2 \%$ & $-\$ 44$ & $21.9 \%$ & $-\$ 47$ \\
\hline
\end{tabular}


2

\begin{tabular}{|c|c|c|c|c|c|c|}
\hline Strategies & $\begin{array}{c}\text { Mean } \\
\text { effectiveness }\end{array}$ & $\begin{array}{l}\text { ICER of the } \\
\text { base case } \\
\text { (USD) }\end{array}$ & $\begin{array}{l}\text { Minimum } \\
\text { effectiveness }\end{array}$ & $\begin{array}{l}\text { ICER } \\
\text { (USD) }\end{array}$ & $\begin{array}{l}\text { Maximum } \\
\text { effectiveness }\end{array}$ & $\begin{array}{l}\text { ICER } \\
\text { (USD) }\end{array}$ \\
\hline $\begin{array}{l}\text { Timolol + Travaprost (Bak } \\
2 \\
3 \text { Free) } \\
4 \\
5 \\
\end{array}$ & $16.5 \%$ & $-\$ 45$ & $14.0 \%$ & $-\$ 44$ & $19.0 \%$ & $-\$ 46$ \\
\hline $\begin{array}{l}6 \text { Timolol + Brinzolamide } \\
7 \\
8\end{array}$ & $17.5 \%$ & $-\$ 32$ & $14.9 \%$ & $-\$ 31$ & $20.1 \%$ & $-\$ 33$ \\
\hline $\begin{array}{l}{ }_{0} \text { Timolol + Brimonidine } \\
11\end{array}$ & $21.0 \%$ & $-\$ 33$ & $17.9 \%$ & $-\$ 32$ & $24.2 \%$ & $-\$ 34$ \\
\hline $\begin{array}{l}22 \text { Brimonidine }+ \text { Brinzolamide } \\
33 \\
4\end{array}$ & $24.5 \%$ & $-\$ 46$ & $20.8 \%$ & $-\$ 44$ & $28.2 \%$ & $-\$ 48$ \\
\hline
\end{tabular}


Table 12. One-way sensitive analysis of micro-bypass trabecular stent versus the laser selective trabeculoplasty surgery and the different drugs combinations for ocular hypertension treatment, adjusted by minimum and maximum costs.

19 20Micro-bypass trabecular 21

22 stent + Timolol 23 24 25 Laser selective 26 27 28 30Dorzolamida 31

32 33Latanoprost + Timolol + 34 35 Dorzolamide 36 37 38 Bimatoprost + Timolol + 39 40 $4{ }_{1}$ Dorzolamide 42 43
44
45
46
47
48 $43_{4}$ Travoprost + Timolol + 45 46Dorzolamide 48 49 Brimonidine + Timolol + 50 51 Dorzolamide 52 53 5 
2

\begin{tabular}{|c|c|c|c|c|c|c|}
\hline Strategies & Mean cost & $\begin{array}{c}\text { ICER of the } \\
\text { base case } \\
\text { (USD) }\end{array}$ & Minimum cost & $\begin{array}{l}\text { ICER } \\
\text { (USD) }\end{array}$ & Maximum cost & $\begin{array}{l}\text { ICER } \\
\text { (USD) }\end{array}$ \\
\hline $\begin{array}{l}1 \text { Timolol + Travaprost (Bak } \\
12 \\
13 \text { Free) } \\
14 \\
15\end{array}$ & $\$ 1.356 .323$ & $-\$ 45$ & $\$ 1.220 .691$ & $-\$ 35$ & $\$ 1.491 .955$ & $-\$ 54$ \\
\hline $\begin{array}{l}16 \text { Timolol + Brinzolamide } \\
\text { 17 } \\
18\end{array}$ & $\$ 1.168 .443$ & $-\$ 32$ & $\$ 1.051 .599$ & $-\$ 24$ & $\$ 1.285 .287$ & $-\$ 40$ \\
\hline $\begin{array}{l}19 \text { Timolol + Brimonidine } \\
20 \\
21\end{array}$ & $\$ 1.168 .443$ & $-\$ 33$ & $\$ 1.051 .599$ & $-\$ 25$ & $\$ 1.285 .287$ & $-\$ 41$ \\
\hline $\begin{array}{l}22 \text { Brimonidine }+ \\
23 \\
24 \\
25 \text { Brinzolamide } \\
26\end{array}$ & $\$ 1.326 .464$ & $-\$ 46$ & $\$ 1.193 .817$ & $-\$ 36$ & $\$ 1.459 .110$ & $-\$ 56$ \\
\hline
\end{tabular}

